\title{
SCIENTIFIC PRODUCTION ON MOBILE INFORMATION LITERACY IN HIGHER EDUCATION: A BIBLIOMETRIC ANALYSIS (2006-2017)
}

\author{
María Pinto
}

Faculty of Information Science. University of Granada (Spain)

Rosaura Fernández-Pascual

Faculty of Economic and Business Sciences. University of Granada (Spain)

David Caballero-Mariscal

Department of Humanities and Social Sciences. University of Granada (Spain)

Dora Sales

Department of Translation and Communication. University Jaume I, Castellón (Spain)

David Guerrero Assessment, Quality and Study Programmes Service. University of Granada (Spain)

Alejandro Uribe Inter-American School of Librarianship. University of Antioquia (Colombia)

\begin{abstract}
This paper offers a bibliometric analysis of the scientific production on Mobile Information Literacy (m-IL) in Higher Education published between 2006 and 2017, taking into account papers covered by Web of Science (WoS), Scopus, Library and Information Science Abstracts (LISA), Library and Information Science and Technology Abstract (LISTA), and Education Resources Information Center (ERIC). Bibliometrics, as an integral part of research evaluation methodology, helps us to identify the subject's evolution over the period studied. In this research we aim to: a) identify the most relevant journals that publish literature in this field, b) calculate the authors' average productivity and identify the most productive authors, and c) discover the most significant trends in this academic field, through statistical and co-occurrence word analyses of the titles and the keywords used to index papers. The bibliometric results of this research provide a snapshot of the literature on Mobile Information Literacy that highlights the most relevant journals, authors, and trending keywords.
\end{abstract}

Keywords: Scientific production, Mobile Information Literacy, Higher Education, bibliometric analysis

\section{INTRODUCTION}

In today's information society, Information Literacy undoubtedly forms the basis for lifelong learning. It is common to all disciplines, to all learning environments, and to all levels of education. It enables learners to master content and to extend their research, become more self-directed, and assume greater control over their own learning. An information-literate individual is able to determine the extent of the information needed, access the required information effectively and efficiently, evaluate the information and its sources critically, incorporate selected information into their knowledge base, use 
information effectively to accomplish a specific purpose, understand the economic, legal and social issues surrounding the use of information, and access and use information both ethically and legally.

In recent years, technological innovations have led to changes in Higher Education, and nowadays face-to-face teaching coexists with blended learning and online teaching. Therefore, the specialized literature puts forward new trends and pedagogical projects in the specific field of Mobile Information Literacy (m-IL), which we intend to tackle in this research.

Our main objective is to provide an up-to-date diagnosis of the scientific production on Mobile Information Literacy in the world over the past decade, taking into account its specific contextual, educational, technological, and research characteristics. Our intention is to gain insights into the development of academic production and, accordingly, the specific goals of this bibliometric study are the following:

a) Identify which journals publish the most on this topic. Thus, we will classify the documents by journal title, as a means of identifying the journals in which most information is found.

b) Identify who the most productive authors are and calculate their average productivity, while also identifying the distribution of scientific production by number of authors.

c) Identify the most significant terms used in the titles and the keywords chosen by the authors to index the contents of their research, and thus discover the most significant trends in the field over the period under study.

\section{LITERATURE REVIEW}

\section{Clarifying concepts}

In our literature review we detected the frequent use of interconnected concepts that come from the interrelated areas of Education, Information, and Computing. Thus, we identified the terms Mobile Learning (m-Learning), Mobile Library (m-Library), Information Literacy (IL) and Mobile Information Literacy ( $m$-IL). In turn, each of these terms implicitly involves other concepts, such as ubiquitous learning, connectivism, and multimodal learning, which we will take into account in what follows.

Walsh (2012a) referred to the relationship between Mobile Learning and Mobile Information Literacy, claiming that both are interrelated and the spread of technology has made access to information ubiquitous in nature. This has not only led to new forms of interpersonal relationships but also to new ways to access information sources, resources production and, hence, new methodologies for the teachinglearning process. In this sense, as Špiranec and Banek (2010) already stated, we may say that there has been a change that has turned the classic conceptions of Information Literacy in a new direction centred on technologies, in this case and more precisely, mobile technologies. Although the spread of the Internet marked an essential turning point, of far-reaching consequences, the use of smartphones has triggered the change from "fixed information research" to "mobile information research" (Walsh, 
2012a: 58; Walsh, 2012b), and this has obvious implications such as accessibility, ubiquity, and immediacy. All these issues make up the descriptive basis of connectivism and navigationism theories that, after the generalization of the use of smartphones, provide chances for continuous and immediate interaction and collaboration (Gikas and Grant, 2013; Serin, 2012).

We should also remark that, on the other hand, when we search for the concept of mobile learning, both in English and in Spanish, other interrelated concepts come up: mobile library, information literacy, and mobile information literacy. According to Fong (2013: 301): "mobile learning is defined as the method in which materials are delivered using mobile technology, such as mobile devices and wireless networks". Thus, these concepts are inevitably related, and the common background for all of them is both the accessibility and the connectivity that enhance the "borderless" nature (Fong, 2013) of the use of mobile devices in daily life, and also their introduction into the educational context.

Taking all this into account, the necessary inter-relationships between $m$-Learning, $m$-Library, IL and $m$ - $I L$ should be enhanced. The educational dimension of $m$-Learning applied to Higher Education, as Virkus (2012) put forward, includes the connection of four factors and their respective dimensions: strategic, educational, professional, and research, all of them interrelated. Following this viewpoint of conceptual relation in the context of Higher Education, authors such as Traxler (2008), Ally (2009), and Hwang and Chang (2011) have highlighted the central role of Libraries as training agents. Specifically, Traxler (2008: 53 ) considered the need to integrate the practices and concepts of all the agents involved in the educational process, as "there is much potential synergy and overlap between the mobile learning community and the $\mathrm{m}$ library community". Though there are also differences, both the m-Learning community and the m-Library community "must understand how mobile technologies transform learning as well as knowledge" (Traxler, 2008: 54). Therefore, it is important to take into account the new Information Literacy frameworks, mainly the proposal from the Association of College and Research Libraries, division of the American Library Association, ACRL-ALA in USA, since they have reduced the well-known standards for Information Literacy (focused on the competencies to be learnt in Higher Education) as they no longer fitted the present-day demands and should be more flexible. Thus, after years of study, the ACRL-ALA proposed the Framework for Information Literacy for Higher Education (ACRL-ALA, 2016).

In this general context of IL in Higher Education, "Mobile Information Literacy" also appears onstage as the subject of discussion as to whether it is a specific form of IL or another multiliteracy-metaliteracy, whether its development should be more prescriptive (Standards-Norms) or more general and flexible (Framework), and whether it should be part of the curriculum or not.

Taking into account the up-to-date and complex nature of the focus of this research, Mobile Information Literacy, part of a paradigm that has evolved with the new technological, pedagogical, and informational developments, it is understandable that scientific production is atomized and produced from diverse viewpoints such as the academic, the pedagogical, the bibliometric and the professional points of view. In this paper we focus on the bibliometric perspective to analyse the situation of scientific production on Mobile Information Literacy in Higher Education, from 2006 to 2017.

The search for "Mobile Information Literacy" in the main databases (Web of Science (WoS), Scopus, Library and Information Science Abstracts (LISA), Library and 
Information Science and Technology Abstract (LISTA), and Education Resources Information Center (ERIC)) offered no bibliometric studies, and therefore we searched for each of the following concepts: Information Literacy, Mobile Learning and Mobile Information Literacy.

\section{Bibliometric studies on Information Literacy}

Taking as a reference the search in the aforementioned databases (Web of Science, Scopus, LISA, LISTA and ERIC) and the recent study by Uribe-Tirado and AlhuayQuispe (2017), fifteen international bibliometric studies have been published in the last decade, analysing the scientific production on Information Literacy. Three trends may be distinguished: a) studies on general production (countries, authors and journals), b) studies focused on subject areas, and c) specific studies on a particular publication and/or context.

The trend regarding general production includes the majority of the bibliometric studies that identify the countries that publish the most, the most productive and most cited authors, the most published journals, languages, etc. (Aharony, 2010; Bhardwaj, 2017; Kolle, 2017; Majid et al., 2015; Sproles, Detmering and Johnson, 2013; Taşkın, Doğan and Şencan, 2013; Park and Kim, 2011). In the field of Social Sciences and Humanities, Bhardwaj (2017), based on Scopus, found a total of 1990 documents published in 160 journals over the period 2001-2012 by authors from 79 countries. Kolle (2017), based on Web of Science for the period 2004-2014, identified 1909 documents in 389 journals by authors from 75 countries. Considering these results, it is clear that the publications on IL have undergone a significant growth in the last two decades, from diverse contexts (more than 70 countries) and several publishing spaces (more than 100 journals), regardless of the database being used. Nonetheless, it is observed that in the last two years there has been a slight decrease, possibly because of the changes that have affected IL both at a terminological level (multiliteracy, transliteracy, media and information literacy) and at a conceptual level (Standards vs. Frameworks). The authors and journals come from USA, United Kingdom, Canada, Australia, China and Spain.

As regards metric studies focused on a subject area perspective, on observing the production in recent years we can see coincidences among the studies. In this sense, Information Science is the most productive area, due to both the specific relationship with IL and the academic affiliation of the authors and the scope of the journals. There are also some studies on scientific production on IL in the areas of Social Sciences and Health Sciences. The major topics are assessment, information competencies, elearning, libraries, and research (Pinto, Escalona and Pulgarín, 2013; Urs et al., 2013; Pinto, 2015). However, in these studies focused on subject area, the references to "Mobile Information Literacy" are scarce.

Finally, regarding specific studies on a particular publication and/or context, we should mention the work by Tallolli and Mulla (2016), which analysed one of the main specialized journals: Journal of Information Literacy. This specific study focuses on the number of citations obtained by papers published in the journal. For instance, 31 papers published in 2015 received 531 citations, with an average of 21.31 citations per paper. It also identifies 155 papers published between 2011 and 2015, by a total of 220 
authors, which again evidence multiple countries and institutions, especially from USA, United Kingdom and Canada. Tallolli and Mulla's work updates another specific research study on the same journal carried out by Panda, Maharana and Chhatar (2013), for the period 2007-2012. These authors showed that the main contributions on IL come from Library and Information researchers. More than half of the authors are from United Kingdom, followed by USA and Canada.

Hsieh, Chuang and Wang (2013) analysed the doctoral theses on IL produced in USA and Taiwan from 1988 to 2010, mainly identifying universities, authors, and research methods. The top producer of scientific literature was USA, again, though an increase was observed in Taiwan.

All in all, these metric studies on IL reflect the dynamics of this field from diverse contexts, but they also prove that Mobile Information Literacy in Higher Education has not been dealt with. This point reveals the appropriateness and timeliness of our bibliometric study, which takes into account the interrelationship among Information Literacy, Mobile Learning, and Mobile Information Literacy.

\section{Bibliometric studies on Mobile Learning and Mobile Information Literacy}

We searched the metric literature on the scientific production regarding "Mobile Learning" and "Mobile Information Literacy", from 2006 to 2017. Results are scarce, although there are some recent bibliometric studies on Mobile Learning that offer a systematic review on this topic. Hsu and Ching (2015) carried out a review based on the models and conceptual frameworks of Mobile Learning, dealing with aspects of the design, assessment, experiences, and research of platforms and learning environments. They underline the efforts put forward by the different works, but they also highlight the limitation of the studies as regards categorization, methodology, and models considered. In spite of its contribution, the study itself is also limited, due to its date of publication because it has been precisely in the last five years when the use of mobile devices in learning contexts has grown exponentially.

Humanante-Ramos, García-Peñalvo and Conde-González (2017) offered another relevant contribution, based on the scientific production present in Scopus and Web of Science over the period 2000-2016. These authors put forward that there are two trends regarding literature reviews on m-Learning: one focused on technical aspects (van Harmelen, 2006; Wilson et al., 2006; Türker and Zingel, 2008; Casquero, Portillo, Ovelar, Benito and Romo, 2010) and a pedagogical one, where some studies on the development of customized learning platforms may be emphasized (Johnson, Hollins, Wilson and Liber, 2006; Adell and Castañeda, 2010; Ebner, Schön, Taraghil, Drachsler and Tsang, 2011; Dabbagh and Kitsantas, 2012; Tomberg, Laanpere, Ley and Normak, 2013).

In a similar line, Brazuelo and Gallego (2014) offered a review on Mobile Learning in Spain, based on the scientific production from 2006 and 2013. Their study stresses the need for a change in educational contexts in order to promote m-Learning, which should be supported by a boost in appropriate educational policies. Mateus, AranRamspott and Masanet (2017) also performed an analysis of the scientific production between 2012 and 2017, based on Scopus and WOS, and focusing on the analysis of authors, references, and methodologies. They highlighted the increase in scientific production since 2012 and the close link between some studies and relevant research 
projects. They also stated that in spite of the importance of this topic for the Education area, publications from this academic membership are scarce.

Focusing on Mobile Information Literacy, it is observed that there are few bibliometric studies and they deal mostly with mobile library. We may highlight the work by Vassilakaki (2014), which describes the mobile services offered by diverse libraries, highlighting the fact that the role of the new library services, based on technology, mobile devices and ubiquity, has to promote a change regarding the traditional concept of the library, its services and possibilities. Likewise, we should mention the work by Blumer and Kenton (2016) (in Briz-Ponce, Juanes-Méndez and García-Peñalvo (2016)), which offers an analysis of the scientific production on academic mobile libraries from 2010 to 2016, underlining the use of new devices, materials and applications. They also cover the use of iPads and QR codes, as well as diverse mobile apps for searching for information. This highlights the necessary intersection between mobile learning and mobile library. In the same way, the role of teachers in the acquisition of information competences becomes a key factor, in cooperation with information professionals.

We should also bear in mind a very significant aspect that is currently increasing: the use of cloud-based apps or platforms. Nowadays the integration of new resources and apps is based on the generalization of cloud-based widgets and mashUps. The combination of these resources with institutional platforms could turn mobile devices into tools that may lead to greater autonomy and critical capacity. Conversely, however, higher education institutions may lose control over the teaching-learning process of their students.

All in all, from the review of the specific literature focused on Mobile Learning and Mobile Information Literacy we observe that there is no comprehensive study that deals with all the scientific production of both concepts from an interrelated viewpoint, as we aim to do in our bibliometric study. As we have seen, there are only partial reviews focused on the context of libraries. This highlights the need to develop bibliometric studies that link both Mobile Information Literacy and Higher Education. In this sense, we consider that this is a pioneering study that will be of interest to know how the current studies on Information Literacy are developing globally, in their borderline relation with other areas such as Education and Information Technologies, creating a bibliometric state of the art on Mobile Information Literacy.

\section{METHODOLOGY}

In the development of our research it was necessary to discuss the search terms, as there are related or similar terms, sometimes belonging to other fields of study. Based on the literature on Information Literacy, Education and Technology applied to Education, and the use of specialized thesauri, first the following search terms were used: information literacy, digital literacy, information competencies, digital competencies, mobile literacy, online learning, ubiquitous learning, mobile telephone, learning smartphone, mobile learning and higher education. A pilot test was carried out with these terms on the LISA and SCOPUS databases, and they proved to be adequate. However, we noticed that if more specific terms such as universities and 
colleges were added, we also obtained documents that did not appear using only higher education.

Finally, the search was carried out on these international databases: Scopus, WoS, LISA, LISTA and ERIC, as they are relevant and appropriate for the subject matter. The inclusion criteria were defined so as to gather only journal papers and main proceedings in English, published from 2006 to September 2017. Thus, books, doctoral theses, and reviews were excluded. We used the following search equation:

(TITLE-ABS-KEY

("information literac*"ORmetaliteracyOR"digitalliterac*"OR"informationcompetenc*"OR"digitalcompetenc*"OR "mobileliterac*") AND TITLE-ABS-KEY ("online learning"OR"ubiquitouslearning"OR"mobiletelephone"OR"cell* phone"OR"learningsmartphone"OR"mobilelearning"OR"mobile training")ANDTITLE-ABS-KEY (universit* OR college OR "higher education")ANDPUBYEAR2006-2017.

Data were gathered in November 2017. After filtering out duplicated records, we standardized the references in the database (MIL database) by regulating characters (capital letters, singular/plural, hyphens, abbreviations) for their further analysis. The total number of references of our corpus amounted to 363 records.

\section{FINDINGS}

The set of 363 references retrieved from the "MIL database" consisted of journal papers $(83.20 \%)$ and conference proceedings $(16.8 \%)$.

The MIL database comes in similar proportions from the ERIC (17\%), LISA (26\%), Library, LISTA (33\%), SCOPUS (20\%) and WOS (4\%) databases.

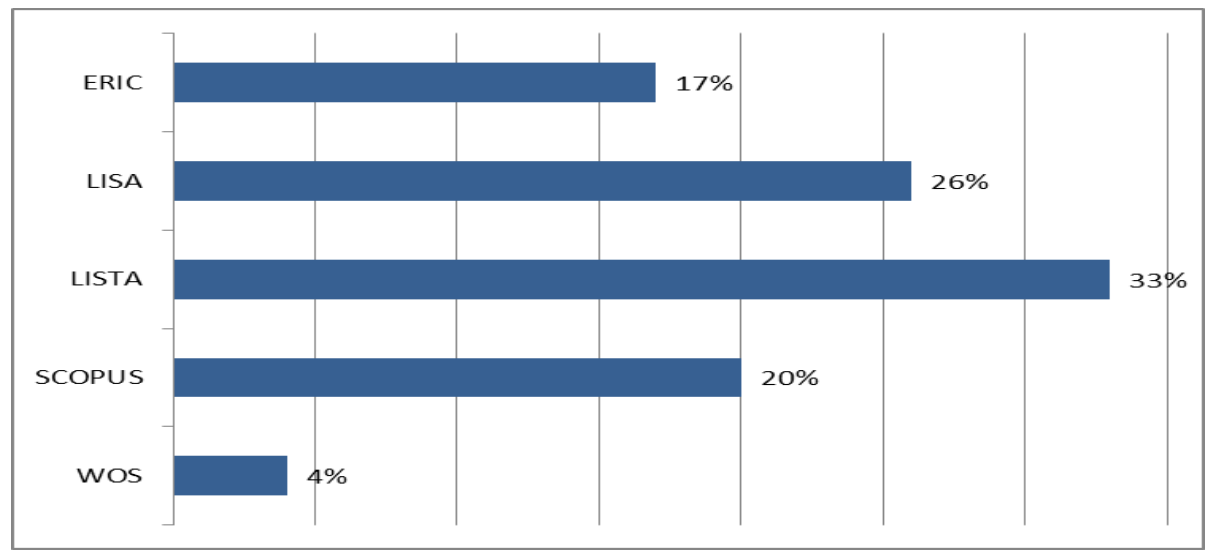

Figure 1: Distribution of references per database in $\%$

The following results provide a descriptive overview of the quantitative scientific production for the period considered. The evolution of publications reveals significant growth, with a polynomial adjustment, that shows two relatively higher points in 2014 and 2016, and minimum points in 2009 and 2017 during the course of the period under study (Figure 2). The figures reflect a decrease during 2017, due to the fact that the research covered the period between January and September of that year. 


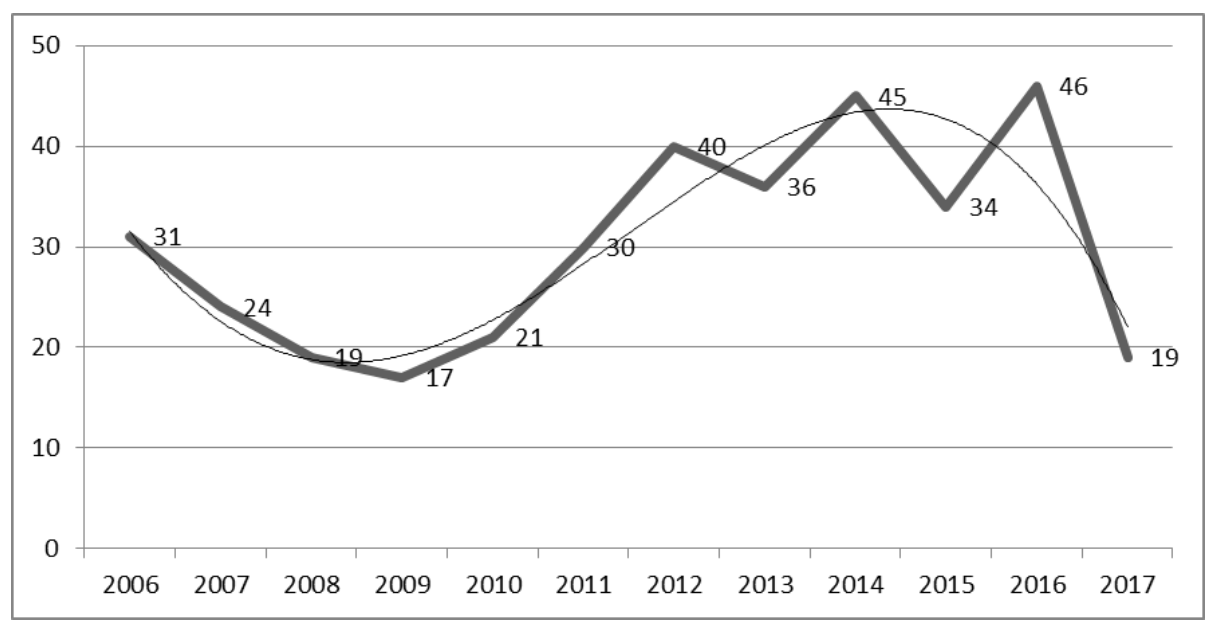

Figure 2: References retrieved. Evolution over time 2006-2017

\section{a) Journals}

There are a total of 161 journals in the retrieved records, and only 17 of them publish more than four papers on the research topic, accounting for $43.8 \%$ of the corpus, as can be observed in Table 1.

\begin{tabular}{|l|c|}
\hline Journal & $\mathrm{n}$ \\
\hline Journal of Library \& Information Services In Distance Learning & 25 \\
\hline Reference Services Review & 15 \\
\hline Communications in Information Literacy & 13 \\
\hline Journal of Academic Librarianship & 13 \\
\hline The Electronic Library & 12 \\
\hline Journal of Library Administration & 11 \\
\hline DESIDOC Journal of Library \& Information Technology & 9 \\
\hline Journal of Information Literacy & 9 \\
\hline IFLA Journal & 8 \\
\hline New Library World & 8 \\
\hline Reference \& User Services Quarterly & 8 \\
\hline College \& Research Libraries and College \& Research Libraries News & 6 \\
\hline Aslib Journal of Information Management and Aslib Proceedings & 5 \\
\hline Portal: Libraries and the Academy & 5 \\
\hline Distributed Learning: Pedagogy and Technology in Online Information Literacy Instruction & 4 \\
\hline Evidence Based Library \& Information Practice & 4 \\
\hline Library Philosophy and Practice & 4 \\
\hline Library Review & 4 \\
\hline Partnership: The Canadian Journal of Library \& Information Practice \& Research & 4 \\
\hline
\end{tabular}

Table 1: Most productive journals 
If we take into account the actual number of publications, it can be observed that five journals have published four papers (5.5\%); nine journals have published three papers (7.4\%); 27 journals have published two papers (4.9\%); and 103 journals have published just one paper, accounting for $28.4 \%$ of the 363 records retrieved (see Table 2 ). This shows a large number of publications are concentrated in a small group of journals.

\begin{tabular}{|c|c|c|c|}
\hline Number of papers & Number of journals & Papers volume \% \\
\hline Five or more & 17 & $10.56 \%$ & $43.80 \%$ \\
\hline 4 & 5 & $3.11 \%$ & $5.51 \%$ \\
\hline 3 & 9 & $5.59 \%$ & $7.44 \%$ \\
\hline 2 & 27 & $16.77 \%$ & $14.88 \%$ \\
\hline 1 & 103 & $63.98 \%$ & $28.37 \%$ \\
\hline Total & 161 & $100 \%$ & $100 \%$ \\
\hline
\end{tabular}

Table 2: Distribution of the number of publications

\section{b) Authors}

According to the records, the 363 references are published by 721 authors. The number of authors ranged from 1 to 10 authors per work. This is directly related to the collaboration between authors, which offers a rate of 2.06 authors per item (Table 3). This collaboration is present in 92 documents, where $26.8 \%$ of the papers are signed by two authors.

\begin{tabular}{|c|c|c|c|}
\hline \multicolumn{1}{c}{$\begin{array}{c}\text { Number of } \\
\text { authors (x) }\end{array}$} & \multicolumn{1}{c}{$\begin{array}{c}\text { Frequency of } \\
\text { references (n) }\end{array}$} \\
\hline 1 & 146 & $42.57 \%$ & 146 \\
\hline 2 & 111 & $32.36 \%$ & 222 \\
\hline 3 & 51 & $14.87 \%$ & 153 \\
\hline 4 & 24 & $7.00 \%$ & 96 \\
\hline 5 & 8 & $2.33 \%$ & 40 \\
\hline 6 & 4 & $1.17 \%$ & 24 \\
\hline 7 & 3 & $0.87 \%$ & 21 \\
\hline 8 & 0 & $0.00 \%$ & 0 \\
\hline 9 & 1 & $0.29 \%$ & 9 \\
\hline Collaboration rate per item & & & 2.06 \\
\hline
\end{tabular}

Table 3: Authors' average productivity 
In order to check whether the distribution of the documents among the authors fits a Zipf distribution (Zipf, 1940) we applied the Kolmogorov-Smirnov non-parametric goodness-of-fit test. The so-called "Zipf's law" is an empirical law according to which for a particular population the frequency of appearance follows a distribution that can be calculated by:

$$
f_{n} \sim 1 / n^{a}
$$

where $f_{n}$ represents the relative frequency of the $n$-th value and ${ }^{a}$ is a positive real number, usually slightly over 1 . To follow a Zipf distribution means that the second element will recur with a frequency of approximately $1 / 2$ that of the first element, the third element will have a frequency of $1 / 3$, and so on. In our case, we have considered $a=1.1$ with a Kolmogorov-Smirnoff $p$-value $>0.05$, thus confirming that Zipf's law is suitable for use in this study as a distribution parameter of scientific production by number of authors.

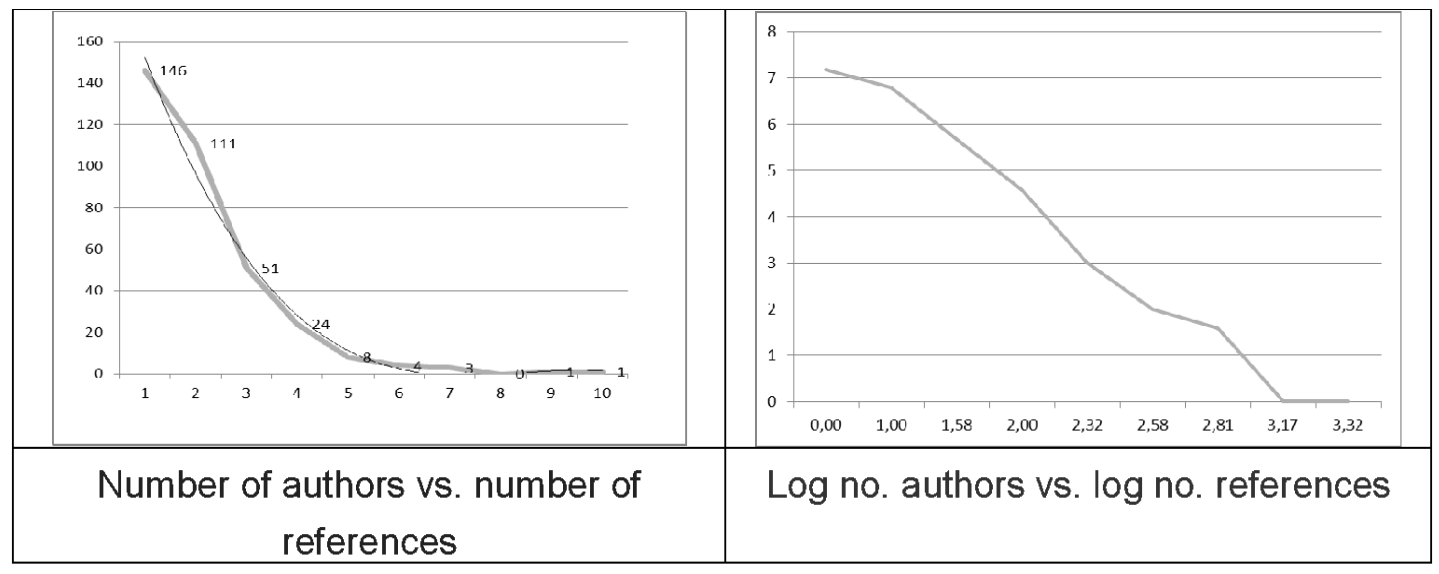

Figure 3: Zipf's mathematical model and its application to scientific production

$84 \%$ of the 721 scholars published just one study, $12 \%$ published two contributions and only the other $4 \%$ published more than 2 studies. Details about professional profile and number of publications by authors with a scientific production higher than two documents are displayed in descending order in Table 4. Regarding the academic affiliation of the authors, USA and Japan stand out, both as regards the number of papers per author and the fact that these two countries appear more than once in the ranking.

\begin{tabular}{l}
\multicolumn{2}{c}{ Surname, Name } & $\begin{array}{c}\text { Number of } \\
\text { papers }\end{array}$ \\
\begin{tabular}{|l|l|c|}
\hline Hess, Amanda Nichols & Oakland University (USA) & 6 \\
\hline Nakayama, Minoru & Tokyo Institute of Technology (Japan) & 5 \\
\hline Yamamoto, Hiroh & Shigshu University, Matsumoto (Japan) & 5 \\
\hline McPherson, Karen & University of Canberra (Australia) & 4 \\
\hline Chatterjee, Parah & National T. University; Buenos Aires (Argentina) & 3 \\
\hline Nath, Asoke & St. Xavier College (Autonomous) (Kolkata, India) & 3 \\
\hline Nunes, Miguel Baptista & School of Information Management, Sun Yat-Sen University SYSU (China) & 3 \\
\hline Santiago, Rowena & California State University San Bernardino (USA) & 3 \\
\hline
\end{tabular}
\end{tabular}




\section{c) Keywords}

\section{Analysis of keywords in titles}

Once the formal aspects related to production, journal and authorship have been dealt with, our aim is to know what the recurrent topics are. To do so, we will analyse the keywords, both in titles and in the terms selected by the authors to index their contributions.

The database search results were used as a basis to label topics within the selected content indicators (title). Once the empty words, such as connectors, prepositions, conjunctions, articles and adjectives, had been deleted, we identified 2811 terms related to the topics of this research. The most frequent words are shown in Table 5.

\begin{tabular}{l|c|l|c|}
\hline Term & Frequency & Term & \multicolumn{1}{l|}{ Frequency } \\
\hline learning & 126 & research & 17 \\
\hline information literacy & 124 & environment & 16 \\
\hline Library & 84 & development & 16 \\
\hline Online & 83 & model & 15 \\
\hline student & 57 & case study & 15 \\
\hline Digital & 37 & higher education & 14 \\
\hline e-learning & 31 & learners & 13 \\
\hline Mobile & 30 & tutorials & 13 \\
\hline instruction & 30 & virtual & 13 \\
\hline university & 29 & design & 12 \\
\hline education & 28 & courses & 11 \\
\hline librarian & 25 & training & 11 \\
\hline academic Skills & 21 & media & 10 \\
\hline technology & 19 & support & $\mathbf{9 6 2 / 2 8 1 1}$ \\
\hline teaching & 18 & services & Total \\
\hline
\end{tabular}

Table 5: The words most commonly used in titles

\section{Analysis of Keywords}

Besides the topic indicators present in titles, the analysis of the keywords chosen by the authors to index the content of their papers is also of great interest. We have identified 2763 keywords that represent the main research subjects in this field. This 
means a ratio of 7.6 keywords/item retrieved. The most frequent keywords are considered in Table 6.

\begin{tabular}{|c|c|c|c|}
\hline Keyword & Frequency & Keyword & Frequency \\
\hline information literacy & 181 & online instruction & 20 \\
\hline academic library & 90 & internet in education & 19 \\
\hline distance education & 67 & library & 19 \\
\hline higher education & 67 & universities \& colleges & 18 \\
\hline online learning & 52 & educational technology & 16 \\
\hline e-learning & 40 & teaching methods & 16 \\
\hline distance learning & 37 & $\begin{array}{l}\text { mobile communication systems in } \\
\text { education }\end{array}$ & 14 \\
\hline Education & 34 & mobile learning & 14 \\
\hline Librarians & 32 & blended learning & 13 \\
\hline information and library science & 29 & information and communication technology & 13 \\
\hline Students & 28 & research & 13 \\
\hline library instruction & 24 & databases & 12 \\
\hline Studies & 24 & teaching & 12 \\
\hline Learning & 23 & undergraduate students & 11 \\
\hline online courses & 23 & digital library & 10 \\
\hline digital literacy & 21 & web-based instruction & 10 \\
\hline \multirow[t]{2}{*}{ mobile devices } & 21 & & \\
\hline & & Total & $1023 / 2763$ \\
\hline
\end{tabular}

Table 6: The most commonly used keywords

\section{VOS Viewer's density and cluster views}

To reveal the most significant trends in the area through out the period under study, we performed a word co-occurrence analysis (Hu, Hu, Deng and Liu, 2013). The most frequent words in titles and keywords were selected, excluding those whose frequency was less than 10 occurrences, as these are considered as being not relevant to the research.

For this purpose, an algorithm that allows the development of a matrix recording the levels of co-occurrence among pairs of keywords (co-occurrence matrix) was developed in Matlab. The 22 and 26 terms with the largest levels of co-occurrence were respectively included in the analysis. Thus, different areas of density of keywords can be obtained, and potential conceptual clustering can also be performed (van Eck and Waltman, 2010).

Density views of the main words in titles (Figure 4) and main keywords (Figure 5) are provided. VOSviewer uses a colour scheme called viridis obtained from Matplotlib, 
a plotting library for the Python programming language. By default, colours range from blue-green to a yellow scheme. Yellow relates to the highest item density (large number of items in the neighbourhood of a point and high weights of the neighbouring items), and blue relates to the lowest item density (small number of items in the neighbourhood of a point and low weights of the neighbouring items). Thus, the size of the label increases with the weight of the item. See van Eck and Waltman (2010) for technical details on the implementation of the density visualization.

The network view is created using the VOS clustering technique, where VOS stands for the visualization of similarities (van Eck and Waltman, 2010). VOSViewer software provides the distance-based maps and identifies the clusters of co-occurring words, which allows us to identify the main terms and the relationships between those terms. We have considered the "total link strength attribute", which indicates the total strength of the links of an item with other items. Colours indicate the cluster to which a term was assigned. To facilitate interpretation, the links in the titles network are displayed using curved lines (Figure 6), and we use straight lines to show the links in the keywords network (Figure 7). 


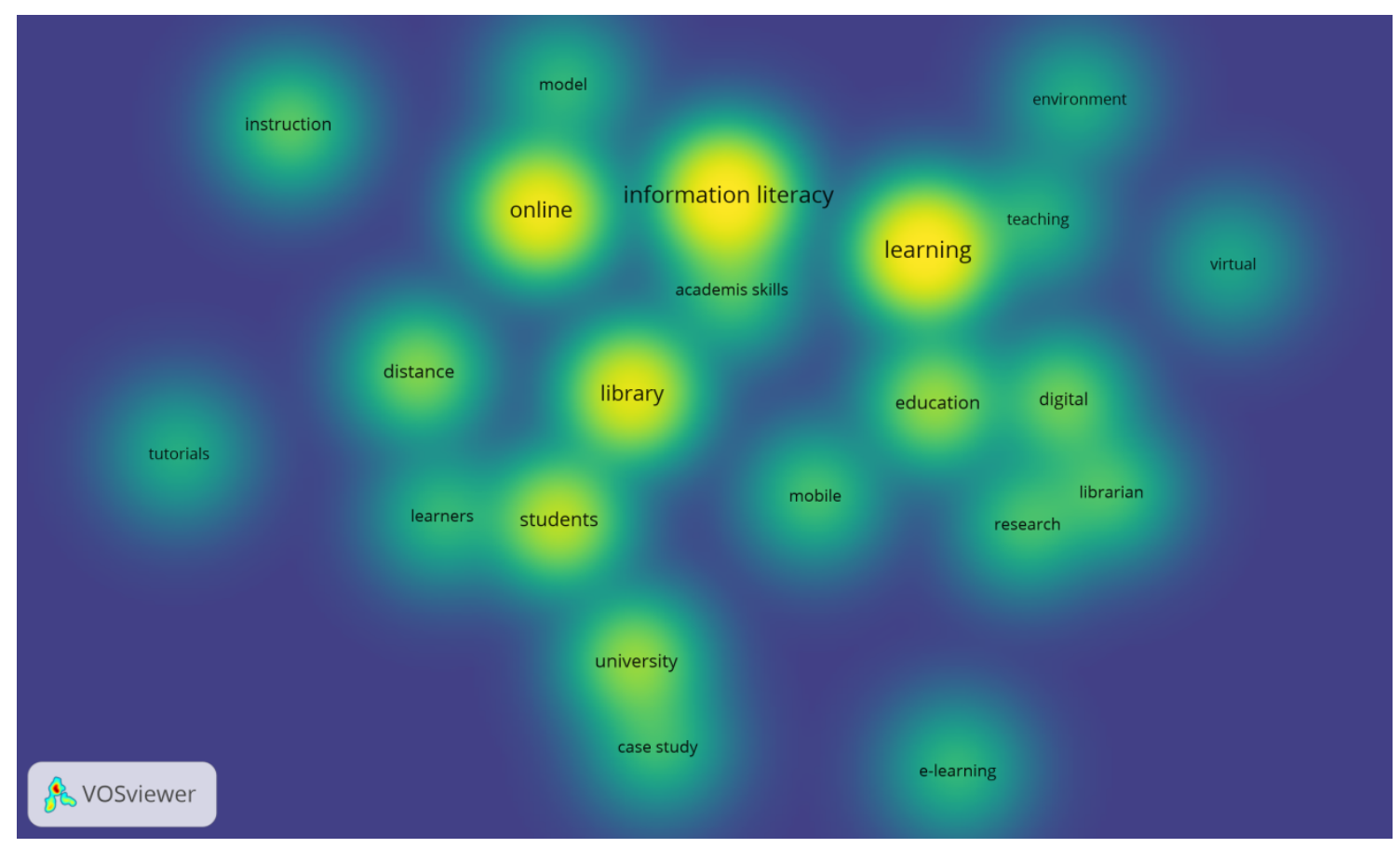

Figure 4: Titles density view

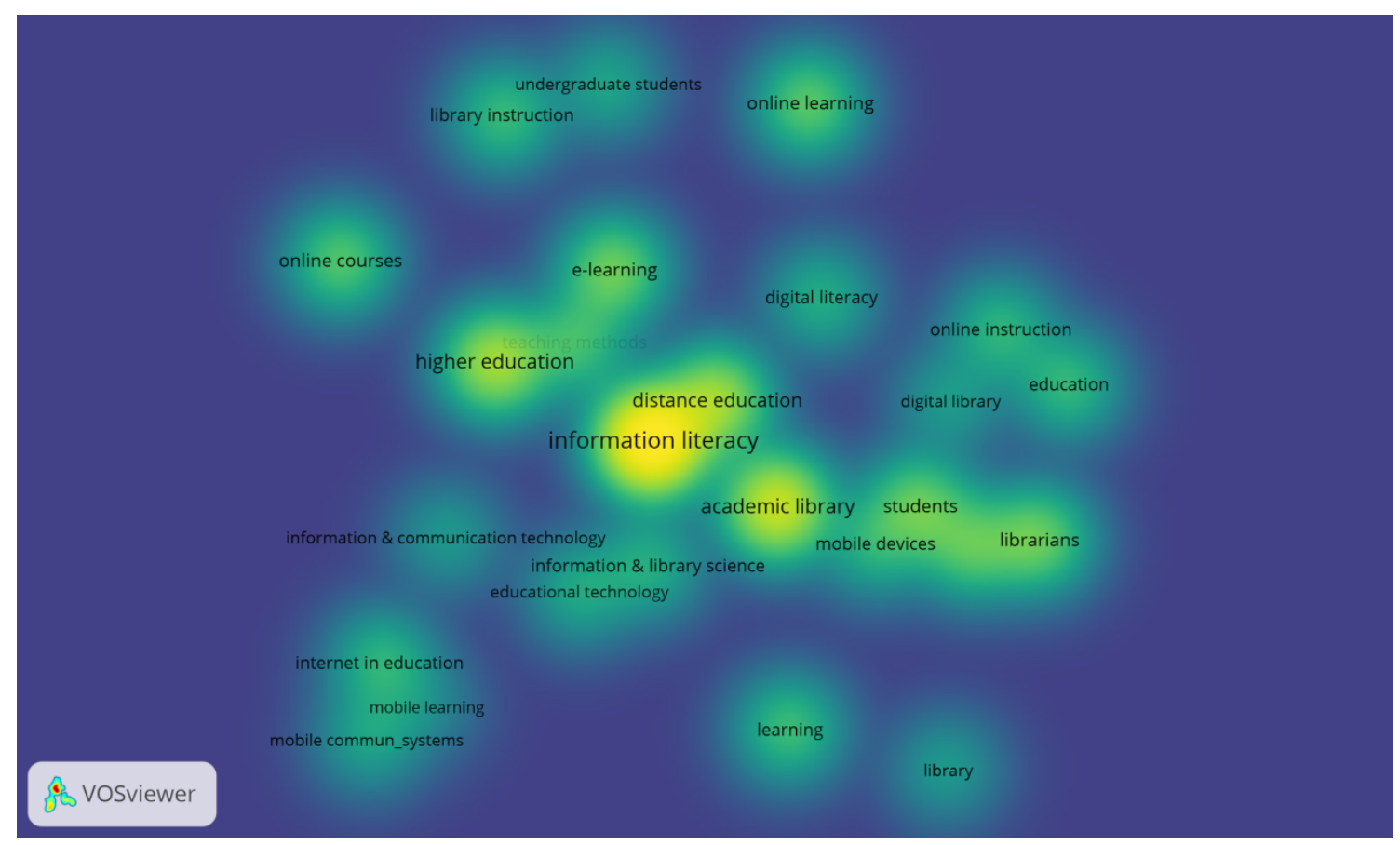

Figure 5: Keywords density view 


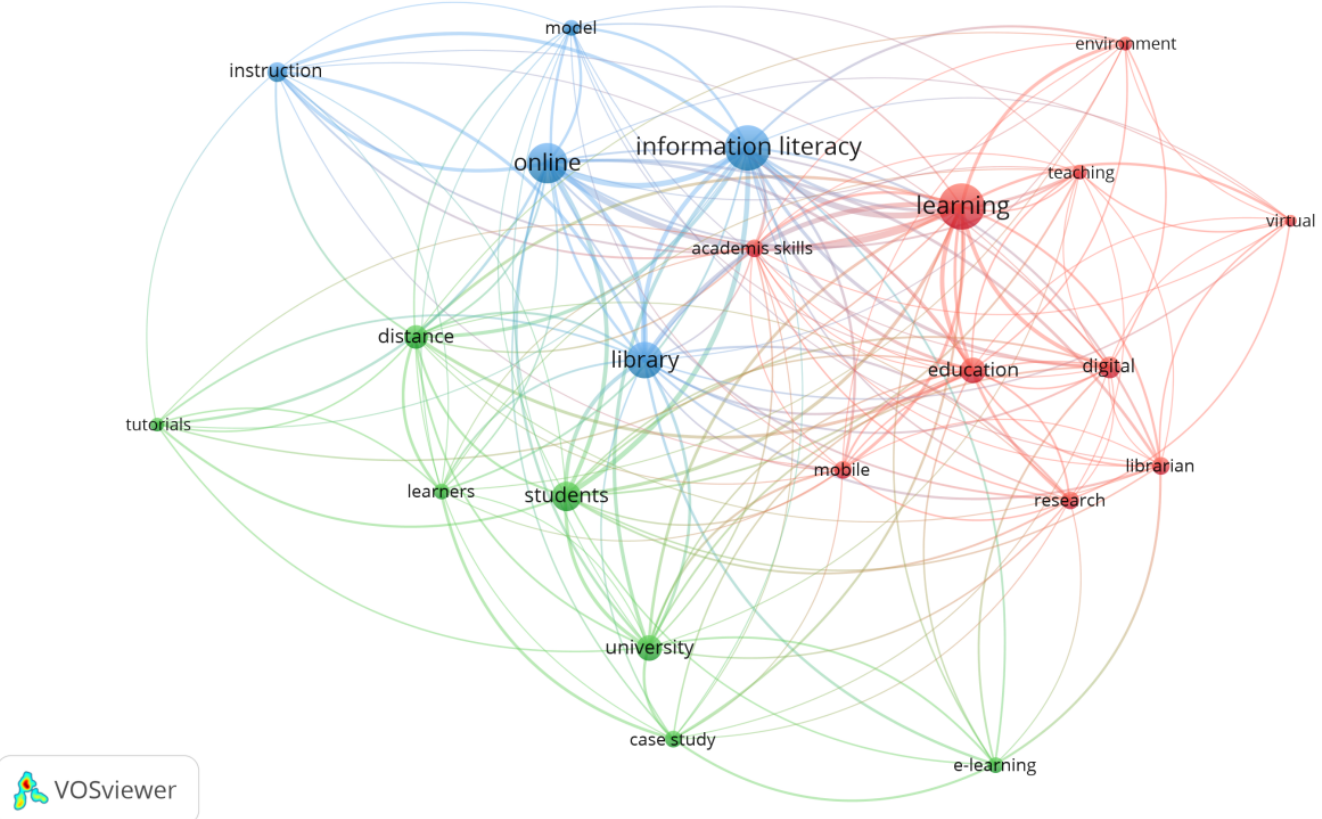

Figure 6: Cluster view of terms in titles

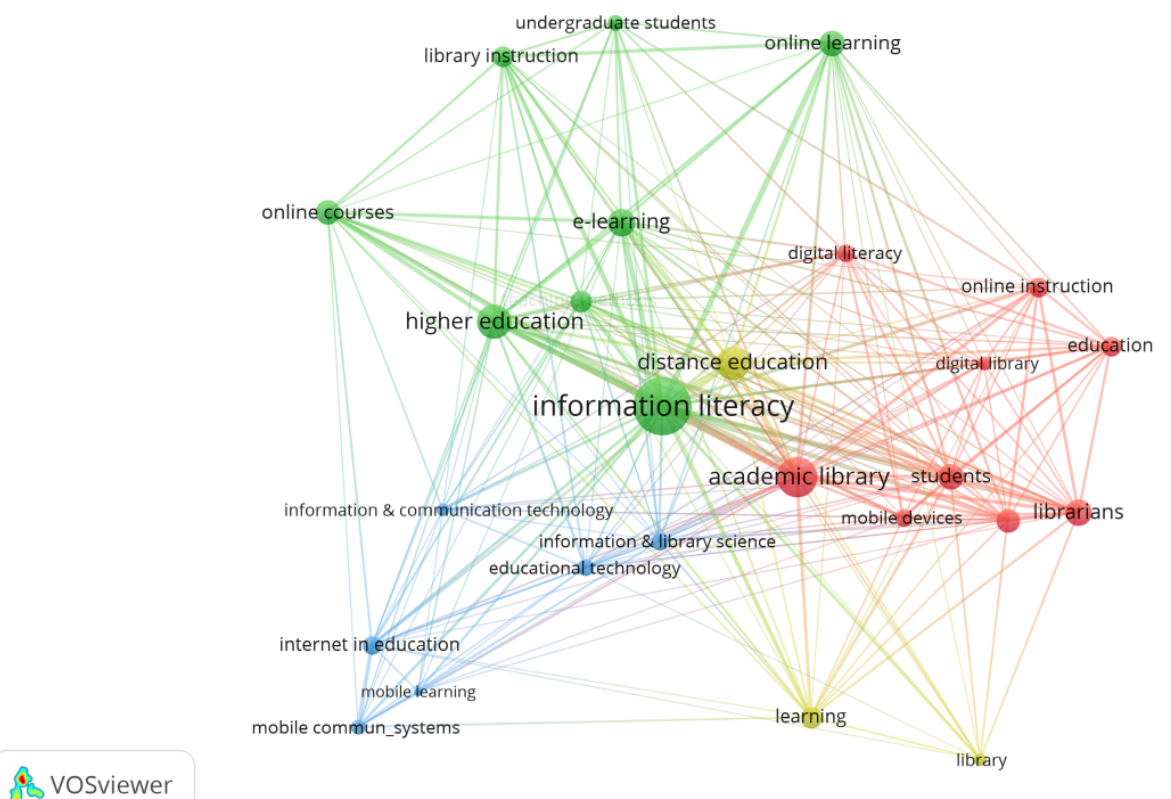

Figure 7: Cluster view of terms in keywords

As can be observed in the above figures, in the titles there is a prevalence of the following terms: Information literacy, library, online, learning, students. On the other hand, regarding keywords, the most commonly used terms are: Information literacy, academic library, distance education, higher education and online learning. Moreover, there are significant intersections and coincidences between both groups (titles and keywords). This shows a specific direction in research contexts, and also a coherence and consistency between the description and the contents of the scientific production in this field. 


\section{DISCUSSION}

At present, it is undeniable that the use of online resources is customary in the field of Information Literacy, especially over the last ten years. This is increasingly more frequently shown in all the specialized literature published over the past decade. Thus, for instance, Anderson and Mitchell (2012) described the benefits and the adaptability that the distance education classroom gains through the use of an online information literacy tutorial that is modular in structure, and "includes interactive exercises, media, and self-testing as well as quizzes that can be graded" (Anderson and Mitchell, 2012: 147).

It is observed, according to the results of our bibliometric analysis, that there is a direct relationship between IL, Higher Education and the new training methodologies. For this reason, the keywords being considered in our study show a higher density as well as the interrelationship and closeness among them (see Figures 4 and 6; clusters 6 and 7 ).

The publications that incorporate $\mathrm{IL}$ in the context of online learning highlight how mobile technologies are gaining ground at all levels. For instance, in Spain, a recent report published by Fundación Telefónica (2017) declared that young people aged between 15 and 24 years are already mainly "mobile first" or "mobile only". That is, a mobile device is their main or even their only tool for searching for and managing information. In the last decade, from the Higher Education area, several authors (Burkhardt and Cohen, 2012; Chatterjee and Nath, 2015; Clark et al., 2017; Day, 2015; Godwin, 2010; Havelka and Verbovetskaya, 2012; Havelka, 2013; Kimberly, 2017; Schmidt, Sanderson and Tin, 2016; Virkus, 2012, among others) have explained their experiences teaching Information Literacy subjects using mobile technologies. All these authors also highlight the need to display a critical perspective when using mobile devices for teaching purposes. In this sense, we can underscore the work by Davis and Smith (2009) on the use of Second Life as a pedagogical tool used by librarians embedded in undergraduate English composition courses. According to the authors, though the tool was already attractive for the students, it was necessary to include pedagogical improvements. In other words, the didactic potentiality does not lie in the technological tools themselves, but in the pedagogical plan that uses them appropriately.

In this same vein, diverse studies on the use of mobile devices for teaching purposes highlight the relevance of motivation as a key element in the teachinglearning process. For instance, Rau, Gao and Wu (2008) already studied the relationship between the use of e-learning and a lower drop-out rate. They also noted a possible higher quality of education. This point was confirmed by the empirical study conducted by Martin and Ertzberger (2013), who compared traditional teaching methods with the use of iPads and iPhones. Their results highlighted the fact that the new online environments promote ubiquity and greater efficiency. Moreover, students declared they felt those environments were familiar to them. Su and Cheng (2015) also related motivation with an improvement regarding results and achievements, but they also dealt with the relevance of gamification in this process. Indeed, mobile devices and apps offer many possibilities and, as Hess (2015: 1) put forward, it is essential that any initiative be developed "considering student motivation", because it "can impact on student learning and achievement". 
Cuthbertson and Falcone (2014) also stressed the need to create learning communities and promote motivation in the context of online courses in information literacy. And among the diverse possibilities offered by online devices, audiovisual material stands out as a tool that increases both motivation and engagement for Information Literacy training (Tang and Chaw, 2016). In this sense, Nakayama, Mutsuura and Yamamoto (2014) reflected on the online teaching-learning process and the necessary information competency it requires, in order to promote a pro-active education, not only for online learning but also for multimodal and blended learning, as also studied by Baker (2016).

Regarding our bibliometric analysis and the trends we have previously described, from the results of the density and cluster views one can infer the complexity and dynamism of this research topic. The density views show the main consolidated research lines, while the clusters show the overall interrelationships. Therefore we can highlight the terms that are more relevant in titles and in keywords (Table 10), as well as the most important clusters.

\begin{tabular}{ll}
\hline & Terms \\
\hline Titles & Information literacy, library, online, learning, students \\
Keywords & $\begin{array}{l}\text { Information literacy, academic library, distance education, higher } \\
\text { education, online learning }\end{array}$ \\
\hline
\end{tabular}

Table 7: Most significant terms

As examples including 4/5 top terms in their titles we could cite the work by Gunn and Kraemer (2011), "The agile teaching library: Models for integrating information literacy in online learning experiences", who discuss four models for integrating IL instruction into computed-based learning processes taking into account the sustainability of the models, and Daniel's (2015) contribution, "Library research courses that follow universal design principles and best practices for online education of special needs students improve student learning experiences". Furthermore, there are 21 documents in the MIL database that include three of the top five terms in their titles.

Regarding keywords, we could mention: Baker (2014), Gunn and Miree (2012), Hemmig, Johnstone and Montet (2012), Mune et al. (2015), Russell et al. (2013), Thornes (2012), Virkus (2006), and Dalal and Lackie (2014), which include 4/5 top keywords (Table 11), and there are 27 documents that include $3 / 5$.

Nonetheless, although it seems that the keywords refer to a reality that may appear to be unified, it is important to point out the thematic diversity of the documents analysed. While there is a common direction regarding methodology and online teaching, the applications are very diverse. Thus, for instance, Baker (2014) focuses on training by means of tutorials, to optimize competencies and skills. Like most of the authors, she highlights the role of libraries. In this same vein, Mune, Goldman, Higgins, Eby, Chan and Crotty (2015) stress the relevance of online modules for Information Literacy training. Dalal and Lackie (2014) go beyond this perspective and emphasize the possibilities offered by social media, which are very commonly used by students, in order to create resources that may support IL training. For their part, Russell, Ryder, Kerins and Phelan (2013: 63) state that "due to the varying perception or understanding of the world held by learners" the reuse of resources, adapted to diverse 
levels and contexts, is needed, together with the implementation of a constructivist model through which the trainees may be protagonists of their own process of competency acquisition. In this sense both trainers and information professionals should turn to the trainees' viewpoint, as regular users of mobile devices, to recycle and reuse methodologies that may fit the ever-changing training needs. In the same vein we could take into account Hung and Zhang's analysis (2012). Using text-mining techniques, they conducted a longitudinal study on the papers published between 2003 and 2008, in order to examine the trends in m-Learning. Based on 119 documents, they chose the most frequently used keywords and the topics derived from their relationship. Their main results showed a very significant growth in the use of mobile devices in Higher Education. This increase has been especially apparent over the last five years, when the use of mobile devices in class has increased fourfold. However, it is noteworthy that m-Learning is still emerging, in spite of the increase in the use of devices. Though it is an unstoppable process, this bibliometric study highlights the fact that more research efforts are needed in terms of studies on strategies and conceptual frameworks, assessment, and customized systems.

It can be seen that there is a range of perspectives and implementations, but all of them come together in the interrelationship among Information Literacy, Higher Education, and online learning. These links are not only present in titles and keywords, but also in the development of the different research papers and literature reviews we have analysed. Moreover, all of them coincide in opening up to the unstoppable changes in educational processes.

\begin{tabular}{|c|c|c|c|c|c|c|}
\hline Reference & $\begin{array}{c}a \\
c \\
a \\
d \\
e \\
m \\
i c \\
l i b \\
r a \\
r y\end{array}$ & $\begin{array}{c}d i \\
s t \\
a \\
n \\
c \\
e \\
e \\
d \\
u \\
c \\
a t \\
i o \\
n\end{array}$ & $\begin{array}{c}h i \\
g \\
h \\
e r \\
e \\
d \\
u \\
c \\
a t \\
i o \\
n\end{array}$ & $\begin{array}{c}\text { in } \\
\text { fo } \\
r \\
m \\
\text { at } \\
\text { io } \\
n \\
\text { lit } \\
e r \\
a \\
c y\end{array}$ & $\begin{array}{c}\text { onli } \\
\text { ne } \\
\text { lear } \\
\text { nin } \\
g\end{array}$ & total \\
\hline Baker (2014) & $x$ & $\mathrm{x}$ & $x$ & $x$ & & 4 \\
\hline Dalal and Lackie (2014) & $x$ & $x$ & & $x$ & $x$ & 4 \\
\hline Gunn and Miree (2012) & & $\mathrm{x}$ & $x$ & $x$ & $\mathrm{x}$ & 4 \\
\hline Hemmig, Johnstone and Montet (2012) & $\mathrm{x}$ & $x$ & $x$ & $x$ & & 4 \\
\hline $\begin{array}{l}\text { Mune, Goldman, Higgins, Eby, Chan and Crotty } \\
\text { (2015) }\end{array}$ & $\mathrm{x}$ & & $x$ & $x$ & $x$ & 4 \\
\hline Russell, Ryder, Kerins and Phelan (2013) & $x$ & & $x$ & $x$ & $\mathrm{x}$ & 4 \\
\hline Thornes (2012) & & $\mathrm{x}$ & $x$ & $x$ & $\mathrm{x}$ & 4 \\
\hline Virkus (2006) & $x$ & $x$ & $x$ & $x$ & & 4 \\
\hline
\end{tabular}

Table 8: References including the most significant terms regarding keywords 
In a similar way we went through the MIL database looking for "prototype/pattern" documents regarding the identified clusters. The results show a clear relationship following the considerations stated above. They also prove that the last decade has been crucial in the scientific production in this field. In this sense, following Gunn and Miree (2012: 18), experimentation and observation lead us to think that a methodology based on an "online IL tutorial is more effective for some skills than for others". The interrelationship between IL, online learning and distance learning is again evident in Higher Education contexts. But the combination of methodologies highlighted by the authors enhances an option that will be recurrent later: blended learning/instruction. This is also the viewpoint of Russell, Ryder, Kerins and Phelan (2013), who, from the constructivism we have previously mentioned, highlighted the need for diverse methods in Higher Education. Mune, Goldman, Higgins, Eby, Chan and Crotty (2015: 101) analysed the dissemination of "courses and programs in hybrid or online-only formats", implicitly drawing attention to the reduction of other formats due to the convenience, immediacy, and effectiveness of hybrid and online options. In any case, the success of a training proposal will be related to the implementation by teachers and professionals as well as the support of the institutions involved (Dalal and Lackie, 2014).

\section{Titles}

Regarding titles, we have considered the keywords organized in the following clusters.

Cluster 1: academic skills, education, environment, learning, librarian, mobile, research, teaching, virtual

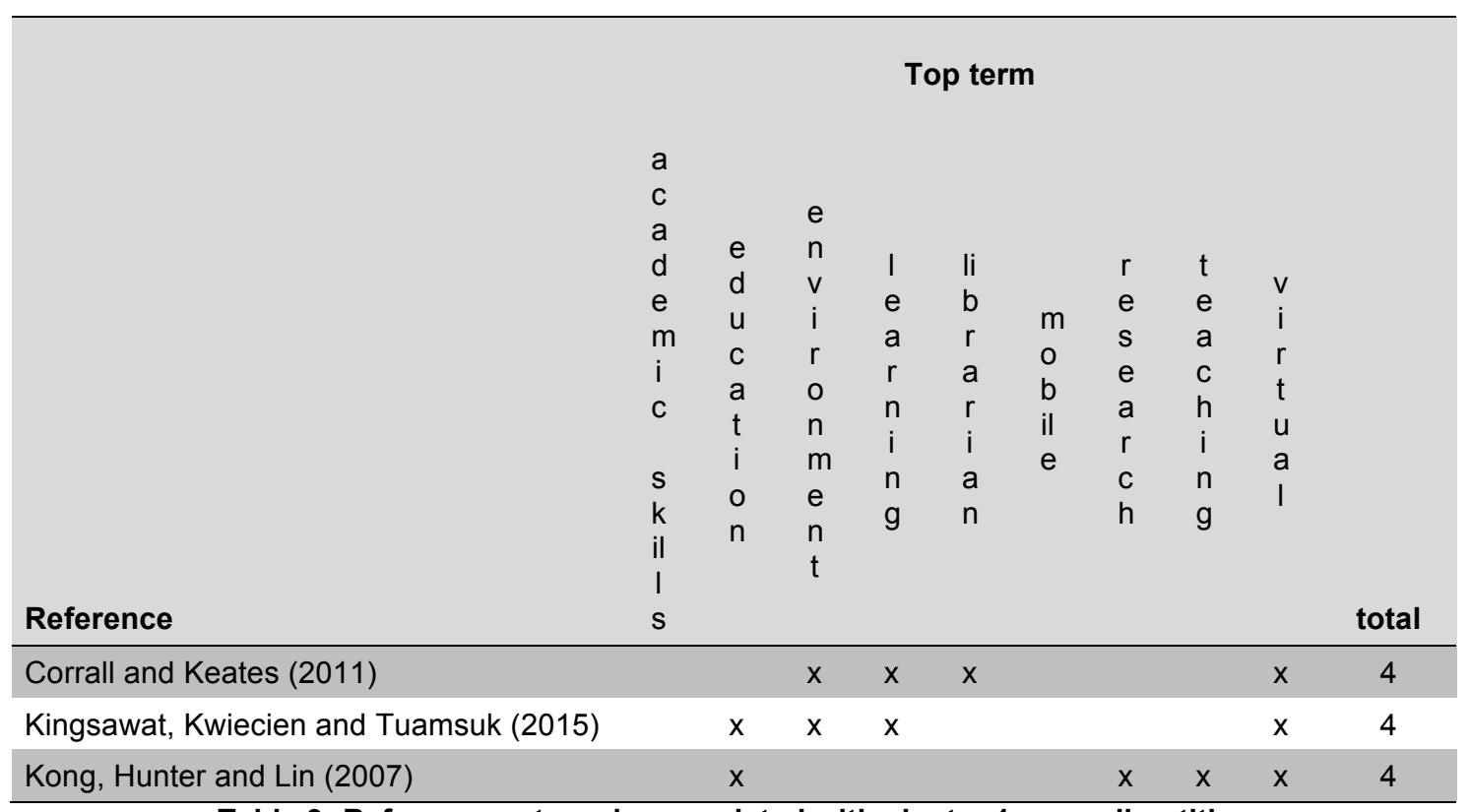

Table 9: References strongly associated with cluster 1, regarding titles

Cluster 2: case study, distance, e-learning, learners, students, tutorials, university 


\begin{tabular}{|c|c|c|c|c|c|c|c|c|}
\hline \multirow[b]{2}{*}{ Reference } & \multicolumn{7}{|c|}{ Top term } & \multirow[b]{2}{*}{ total } \\
\hline & $\begin{array}{l}\mathrm{s} \\
\mathrm{t} \\
\mathrm{u} \\
\mathrm{d} \\
\mathrm{y}\end{array}$ & $\begin{array}{l}\mathrm{d} \\
\mathrm{i} \\
\mathrm{s} \\
\mathrm{t} \\
\mathrm{a} \\
\mathrm{n} \\
\mathrm{c} \\
\mathrm{e}\end{array}$ & $\begin{array}{c}\mathrm{e} \\
- \\
\mathrm{l} \\
\mathrm{e} \\
\mathrm{a} \\
\mathrm{r} \\
\mathrm{n} \\
\mathrm{i} \\
\mathrm{n} \\
\mathrm{g}\end{array}$ & $\begin{array}{l}\mathrm{l} \\
\mathrm{e} \\
\mathrm{a} \\
\mathrm{r} \\
\mathrm{n} \\
\mathrm{e} \\
\mathrm{r} \\
\mathrm{s}\end{array}$ & $\begin{array}{l}\mathrm{s} \\
\mathrm{t} \\
\mathrm{u} \\
\mathrm{d} \\
\mathrm{e} \\
\mathrm{n} \\
\mathrm{t} \\
\mathrm{s}\end{array}$ & $\begin{array}{l}\mathrm{t} \\
\mathrm{u} \\
\mathrm{t} \\
\mathrm{o} \\
\mathrm{r} \\
\mathrm{i} \\
\mathrm{a} \\
\mathrm{l} \\
\mathrm{s}\end{array}$ & $\begin{array}{c}\mathrm{u} \\
\mathrm{n} \\
\mathrm{i} \\
\mathrm{v} \\
\mathrm{e} \\
\mathrm{r} \\
\mathrm{s} \\
\mathrm{i} \\
\mathrm{t} \\
\mathrm{y}\end{array}$ & \\
\hline Greenlee (2014) & & $x$ & & $\mathrm{x}$ & & $x$ & & 3 \\
\hline Kratochvil (2014) & & & $\mathrm{x}$ & & $\mathrm{x}$ & & $\mathrm{x}$ & 3 \\
\hline Kumar (2016) & $x$ & & & & $\mathrm{x}$ & & $x$ & 3 \\
\hline Moghaddam and Fard (2013) & $x$ & $x$ & & & & & $x$ & 3 \\
\hline Wales and Robertson (2008) & & & & & $x$ & $x$ & $x$ & 3 \\
\hline Walters, Bolich, Duffy, Quinn, Walsh and Connolly (2015) & & & & & $x$ & $x$ & $x$ & 3 \\
\hline Washburn (2009) & & $x$ & & $x$ & & $x$ & & 3 \\
\hline Woodward (2015) & & $x$ & & & $x$ & & $x$ & 3 \\
\hline
\end{tabular}

Cluster 3: information literacy, instruction, library, model, online

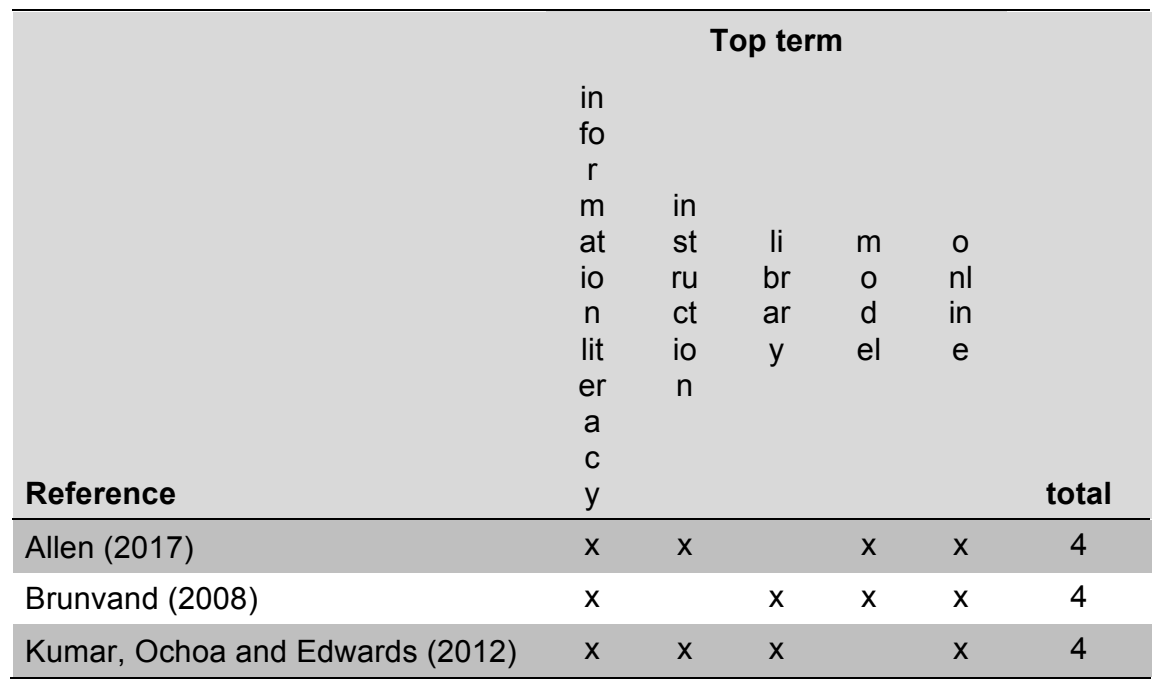

Table 11: References strongly associated with cluster 3 , regarding titles

\section{Keywords}

Regarding Keywords, we have also considered the top terms organized in clusters, as follows:

Cluster 1: Academic library, digital library, digital literacy, distance learning, education, librarians, mobile devices, online instruction, students. 
Regarding the keyword "mobile devices", Tang and Chaw (2016) offered a study on students' efficiency in a flexible and hybrid learning environment, based on the use of mobile devices (mainly tablets and smartphones) and web-based services. The authors analysed the relationship between four key issues in digital literacy: concepts, previous knowledge, central competencies, and attitudes and perspectives. The analysis of the statistical factor suggests that the term "digital literacy" has significant statistical relationships with effective learning.

On the other hand, Mullins (2017) conducted a study focused on the experience of university students in New York using apps to search for information, and the implementation of apps by librarians. The adaptability of information professionals is a key element to deal with the users' needs and the potentiality of new contexts and tools. As stated by Hahn (2008: 277), at the dawn of mobile teaching "learning can occur in a just-in-time manner for our users and students, by way of content that is equally of adequate size for time constraints". This has become a growing reality in recent years. Thus, Courtney and Wilhoite-Mathews (2015) presented the transition from distance learning to online learning as a fact that already exists. In this sense, mobile devices are a basic working tool for students, teachers, and librarians.

\begin{tabular}{|c|c|c|c|c|c|c|c|c|c|c|}
\hline \multirow[b]{2}{*}{ Reference } & \multicolumn{10}{|c|}{ Keyword } \\
\hline & $\begin{array}{l}\mathrm{a} \\
\mathrm{c} \\
\mathrm{a} \\
\mathrm{d} \\
\mathrm{e} \\
\mathrm{m} \\
\text { ic } \\
\mathrm{l} \\
\mathrm{b} \\
\mathrm{r} \\
\mathrm{a} \\
\text { ry }\end{array}$ & $\begin{array}{c}\mathrm{di} \\
\mathrm{gi} \\
\mathrm{ta} \\
\mathrm{l} \\
\mathrm{li} \\
\mathrm{b} \\
\mathrm{r} \\
\mathrm{a} \\
\mathrm{ry}\end{array}$ & $\begin{array}{c}\mathrm{di} \\
\mathrm{gi} \\
\mathrm{ta} \\
\mathrm{l} \\
\mathrm{lit} \\
\mathrm{e} \\
\mathrm{r} \\
\mathrm{a} \\
\mathrm{c} \\
\mathrm{y}\end{array}$ & $\begin{array}{c}\mathrm{di} \\
\mathrm{st} \\
\mathrm{a} \\
\mathrm{n} \\
\mathrm{c} \\
\mathrm{e} \\
\mathrm{le} \\
\mathrm{a} \\
\mathrm{r} \\
\mathrm{ni} \\
\mathrm{n} \\
\mathrm{g}\end{array}$ & $\begin{array}{l}\mathrm{e} \\
\mathrm{d} \\
\mathrm{u} \\
\mathrm{c} \\
\text { at } \\
\text { io } \\
\mathrm{n}\end{array}$ & $\begin{array}{l}\text { li } \\
\text { b } \\
r \\
a \\
\text { ri } \\
\text { a } \\
\text { n } \\
\mathrm{s}\end{array}$ & $\begin{array}{c}\mathrm{m} \\
\mathrm{o} \\
\mathrm{bi} \\
\mathrm{le} \\
\mathrm{d} \\
\mathrm{e} \\
\mathrm{vi} \\
\mathrm{c} \\
\mathrm{e} \\
\mathrm{s}\end{array}$ & $\begin{array}{l}\mathrm{o} \\
\mathrm{nl} \\
\text { in } \\
\mathrm{e} \\
\text { in } \\
\mathrm{st} \\
\mathrm{r} \\
\mathrm{u} \\
\mathrm{ct} \\
\text { io } \\
\mathrm{n}\end{array}$ & $\begin{array}{c}\text { st } \\
\text { u } \\
\text { d } \\
\text { e } \\
\text { nt } \\
\text { s }\end{array}$ & total \\
\hline Mullins (2017) & $\mathrm{x}$ & & $\mathrm{x}$ & & & $\mathrm{x}$ & $x$ & & $\mathrm{x}$ & 5 \\
\hline Ukwoma, Iwundu and Iwundu (2016) & $x$ & $x$ & $x$ & & $\mathrm{x}$ & $x$ & & & & 5 \\
\hline Tang and Chaw (2016) & & $x$ & $x$ & & $\mathrm{x}$ & & $x$ & & $x$ & 5 \\
\hline
\end{tabular}

Table 12: References strongly associated with cluster 1, regarding keywords

Cluster 2: e-learning, higher education, information literacy, library instruction, online courses, online learning, teaching methods, undergraduate students.

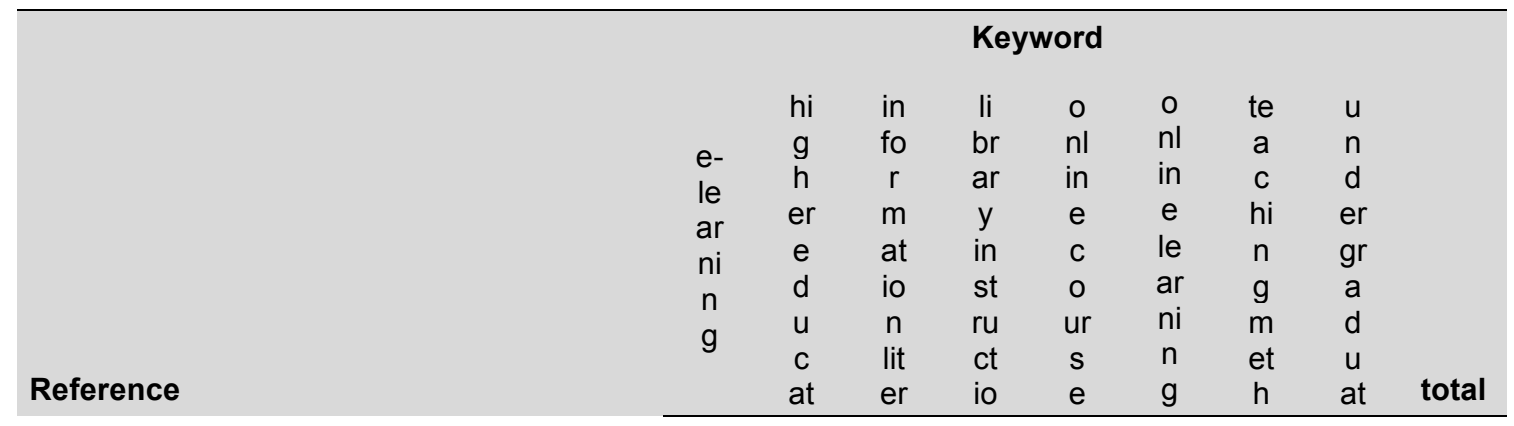




\begin{tabular}{|c|c|c|c|c|c|c|c|c|}
\hline & & $\begin{array}{l}\text { io } \\
\mathrm{n}\end{array}$ & $\begin{array}{l}a \\
c \\
y\end{array}$ & $\mathrm{n}$ & $\mathrm{s}$ & $\begin{array}{l}\text { o } \\
\text { d } \\
\text { s }\end{array}$ & $\begin{array}{c}\mathrm{e} \\
\mathrm{st} \\
\mathrm{u} \\
\mathrm{d} \\
\mathrm{e} \\
\mathrm{nt} \\
\mathrm{s}\end{array}$ & \\
\hline Bell (2007) & & $x$ & $x$ & $x$ & $x$ & $x$ & $x$ & 6 \\
\hline $\begin{array}{l}\text { Mestre, Baures, Niedbala, Bishop, Cantrell, } \\
\text { Perez and Silfen (2011) }\end{array}$ & $x$ & $x$ & $x$ & $x$ & $x$ & $x$ & & 6 \\
\hline Baker (2014) & & $\mathrm{x}$ & $x$ & $x$ & $x$ & $x$ & & 5 \\
\hline Greer, Hess and Kraemer (2016) & & $x$ & $x$ & $x$ & $x$ & $x$ & & 5 \\
\hline Jacobs (2017) & $x$ & 2 & $x$ & $x$ & $x$ & & & 5 \\
\hline Ladell-Thomas (2012) & $x$ & 2 & $x$ & $x$ & $x$ & & & 5 \\
\hline Mery, DeFrain, Kline and Sult (2014) & & 2 & $x$ & & $x$ & $x$ & $x$ & 5 \\
\hline Nakayama, Mutsuura and Yamamoto (2014) & $\mathrm{x}$ & $x$ & $x$ & & $x$ & & $x$ & 5 \\
\hline
\end{tabular}

Table 13: References strongly associated with cluster 2 , regarding keywords

Cluster 3: educational technology, information \&communication technology, information \& library science, Internet in education, mobile communication systems, mobile learning.

At this point, we should mention the work by Gallego, Cristóbal, Alberto, Arribas and Rubia (2016), who included three of the top six keywords in their analysis of ubiquitous education based on the experience of students of Primary Physical Education. Their results highlight the fact that ubiquitous learning motivates and encourages students to interact with the process of teaching from diverse contexts.

\section{Cluster 4: distance education, learning, library.}

In this case we should take into account the work by Glassman and Worsham (2017), who used the three keywords of this cluster. Their study is focused on the experience of an Information Literacy training program, its development, implementation, and assessment. A hybrid model is proposed, based on a one-shot course and a complete course, as was also suggested by Mullins (2017). However, Peter, Leichner, Mayer and Krampen (2017) proposed to increase the resources and methods to teach IL, substituting the one-shot courses by a methodology that may adapt to the needs of university students. This point had been highlighted years before by Mery, Newby and Peng (2012), who already questioned whether one-shot courses could be the future for IL acquisition.

\section{The situation of the term Mobile}

In the documents considered, the word mobile offers direct connections with 16 terms in the titles (Figure 8). The strongest links are related to learning, information literacy, university and education. 


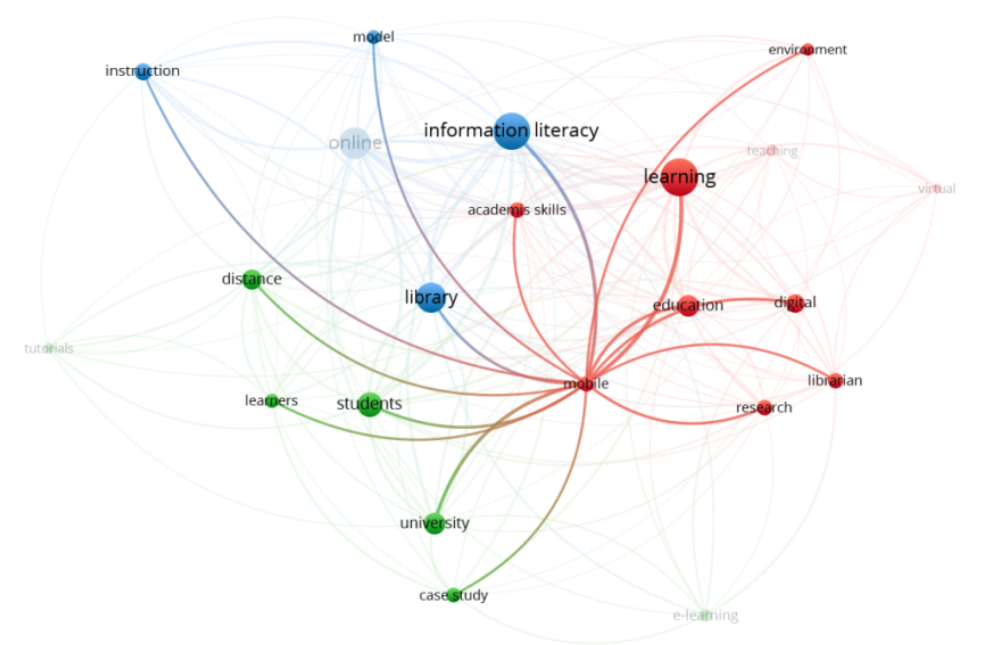

Figure 8: Mobile relationships in titles

In the keywords, we have found the word mobile in three terms: mobile communication systems in education, mobile learning, and mobile devices. Connections are displayed in Figures 9-11. In the first case, the strongest connections are related to Internet in education and information literacy. In the case of mobile learning, the links are stronger with information literacy, higher education, and Internet in education. Finally, the strongest links of mobile devices are related to information literacy, higher education, academic library, students, and education.

The presence of the term mobile in the two scenarios we are dealing with in our study (titles and keywords) underlines the growing relevance of the use of mobile devices. They are increasingly present in academic contexts as an inexhaustible source of pedagogical resources. And this is also the case for Information Literacy. The strong link with the term education shows that, both in Mobile Learning and Information Literacy, mobile devices are becoming more widespread at all educational levels. This is gradually becoming a generalized reality in Higher Education.

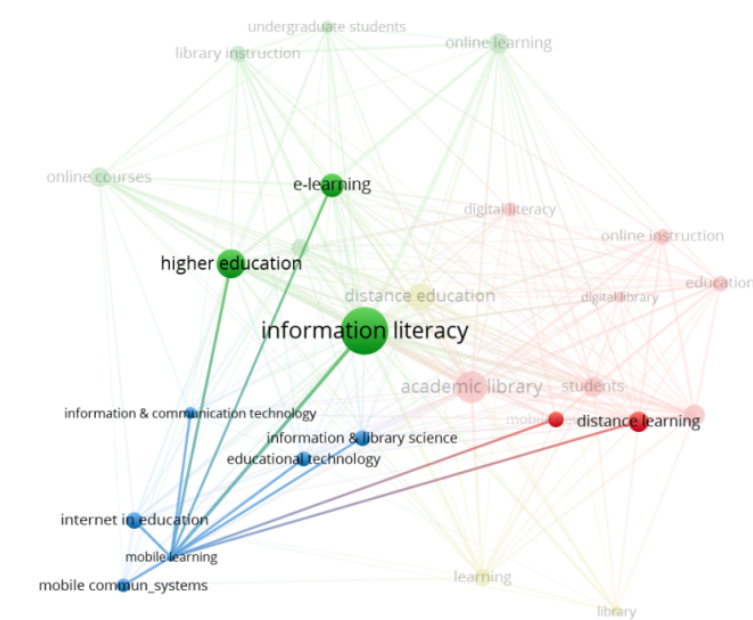

Figure 9: Mobile relationships in keywords: the case of mobile learning 


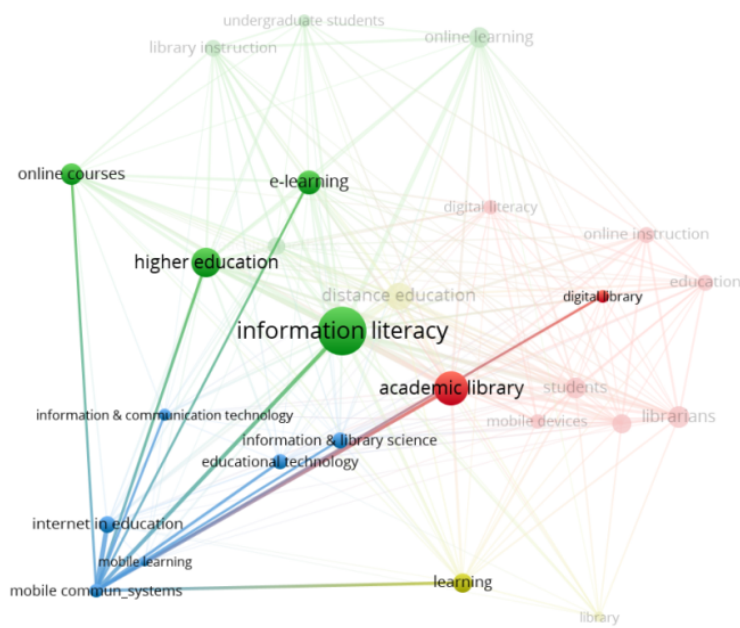

Figure 10: Mobile relationships in keywords: the case of mobile communication systems in education

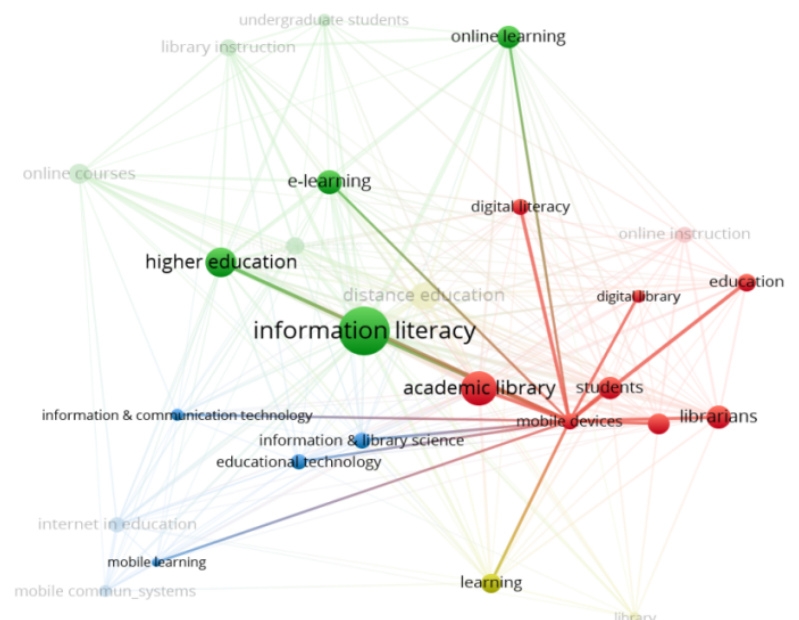

Figure 11: Mobile relationships in keywords: the case of mobile devices

\section{CONCLUSIONS AND FUTURE RESEARCH}

After our bibliometric analysis on international scientific production on Mobile Information Literacy, which is an interdisciplinary topic that has only recently emerged, there are some points to be stressed.

On the one hand, there is a clear prevalence of specific terminology in the titles of publications (Information literacy, library, online, learning, students) and in the keywords chosen by the authors (information literacy, academic library, distance education, higher education, and online learning). As has been stated earlier, there are relevant interconnections and convergences between titles and keywords. This proves that there is coherence between the contents and the description of the contributions 
published on Mobile Information Literacy. This is further confirmed if we take into account the contents of the most relevant scientific production, regarding the frequency of use of the key terms. It should be pointed out that the type of publication (that is, literature review, quantitative research, case study or even meta-analysis) makes no difference regarding frequency. Nonetheless, this interrelationship may become an issue to deal with in the future. Although online learning, distance learning and mobile devices are, together with the top term (information literacy), among the most frequently used, this is not yet the case with mobile learning. This shows that it is a topic that is expanding and, also, it is going to open up multiple viewpoints in coming years.

On the other hand, although there are bibliometric analyses related to each of the issues we have mentioned, there are none that join IL, mobile learning, and Higher Education. In this regard, the present study aims to provide an integrated perspective that is indeed present in the empirical and review studies, but was absent in the bibliometric field.

The use of mobile devices in class is an unstoppable reality that is also becoming essential for the development of teaching-learning processes in Higher Education. Ubiquity and the new learning scenarios are bringing about a transformation in the way to access, manage, and use information in both daily and academic life. Due to the use of mobile technology in teaching-learning methodologies, there seems to be an increase in students' motivation. According to our findings, there is an obvious interrelation between the terms mobile, teaching, information literacy and Higher Education. Therefore, the presence of the term mobile both in keywords and titles confirms the growing relevance of this topic.

In future work, it would be interesting to describe the most frequent keywords in titles after gathering them in thematic clusters defined by experts from the academic fields involved, and also to analyse the relationship between the most frequent terms and the different research methodologies (from literature reviews to empirical studies). As another future line of research it would also be thought provoking to include the possibility to extend the study to databases, sources and resources of "smaller" indexation. And, regarding mobile devices, it should be relevant to include the reference to tablets.

\section{Acknowledgement}

This research is part of the R\&D project "Innovation and training in the information competencies of university lecturers and students in the social sciences. Model for the development of programs in the mobile environment" (CSO2016-80147-R), funded by the Spanish Ministry of Economy, Industry and Competitiveness.

\section{REFERENCES}


ACRL-ALA. Association of College and Research Libraries (2016), Framework for Information Literacy for Higher Education. Association of College and Research Libraries, a division of the American Library Association.

Adell, J., \& Castañeda, L. (2010). Los Entornos Personales de Aprendizaje (PLEs): una nueva manera de entender el aprendizaje. In R. Roig Vila \& M. Fiorucci (Ed.), Claves para la investigación en innovación y calidad educativas. La integración de las Tecnologías de la Información y la Comunicación y la Interculturalidad en las aulas (pp. 19-30). Alcoy: Marfil - Rome: TRE Universita degli studi.

Aharony, N. (2010). Information Literacy in the Professional Literature: An Exploratory Analysis. Aslib Proceedings, 62(3), 261-282.

Allen, M. (2017). Designing Online Asynchronous Information Literacy Instruction Using the ADDIE Model. In Maddison, T. \& Kumaran, M. (2017). Distributed Learning Pedagogy and Technology in Online Information Literacy Instruction. London: Chandos Information Professional Series (pp. 69-91).

Ally, M. (Ed.) (2009). Mobile Learning: Transforming the Delivery of Education and Training. Athabasca: Athabasca University Press.

Anderson, S. A. \& Mitchell, E. R. (2012). Life after TILT: Building an Interactive Information Literacy Tutorial. Journal of Library \& Information Services in Distance Learning, 6(3-4), 147-158.

Baker, A. (2016). Active Learning with Interactive Videos: Creating StudentGuided Learning Materials. Journal of Library \& Information Services in Distance Learning, 10(3-4), 79-87.

Baker, R. L. (2014). Designing LibGuides as Instructional Tools for Critical Thinking and Effective Online Learning. Journal of Library \& Information Services in Distance Learning, 8(3-4), 107-117.

Bell, C. (2007). Technology: Ten Years after TILT--New Uses of Technology to Promote Information Literacy. Public Services Quarterly, 3, 257-267.

Bhardwaj, R. K. (2017). Information Literacy Literature in the Social Sciences and Humanities: A Bibliometric Study. Information and Learning Science, 118(1/2), 67-89.

Brazuelo Grund, F., \& Gallego Gil, D. J. (2014). Estado del mobile learning en España. Educar em Revista, (4). http://www.scielo.br/scielo.php?pid=S010440602014000800099\&script=sci_abstract\&tlng=es. Accessed 1 February 2018.

Briz-Ponce, L., Juanes-Mendez, J. A., \& García-Peñalvo, F. J. (Eds.) (2016). Handbook of Research on Mobile Devices and Applications in Higher Education Settings. Hershey, PA (USA): IGI Global.

Brunvand, A. (2008). Integrating library reference services in an online information literacy course: The Internet Navigator as a model. Internet Reference Services Quarterly, 9(3-4), 159-177.

Burkhardt, A., \& Cohen, S.F. (2012). "Turn Your Cell Phones On”. Mobile Phone Polling as a Tool for Teaching Information Literacy. Communications in Information Literacy, 6(2), 191. http://digitalcommons.calpoly.edu/lib_fac/96/ Accessed 16 October 2017.

Casquero, O., Portillo, J., Ovelar, R., Benito, M., \& Romo, J. (2010). iPLE Network: An Integrated eLearning 2.0 Architecture from a University's Perspective. Interactive Learning Environments, 18(3), 293-308.

Chatterjee, P., \& Nath, A. (2015). The Future ICT Education in India-A Pilot Study on the Vision of Ubiquitous Learning in Higher Education. In S. C. Satapathy et al. (Eds.), Information Systems Design and Intelligent Applications (pp. 599-609). New Delhi: Springer.

Clark, M., Coward, C., Rothschild, C., Reynal, L. D., Richter, B. (2017). Towards a Mobile Information Literacy Framework: Rethinking Information Literacy in a Mobile Era. iConference 2017 Proceedings. https://www.ideals.illinois.edu/handle/2142/96782 Accessed 16 October 2017. 
Corrall, S., \& Keates, J. (2011). The Subject Librarian and the Virtual Learning Environment: A Study of UK Universities. Program, 45(1), 29-49.

Courtney, M., \& Wilhoite-Mathews, S. (2015). From Distance Education to Online Learning: Practical Approaches to Information Literacy Instruction and Collaborative Learning in Online Environments. Journal of Library Administration, 55(4), 261-277.

Cuthbertson, W. \& Falcone, A. (2014). Elevating Engagement and Community in Online Courses. Journal of Library \& Information Services in Distance Learning, 8(3-4), 216-224.

Dabbagh, N., \& Kitsantas, A. (2012). Personal Learning Environments, Social Media, and Self-Regulated Learning: A Natural Formula for Connecting Formal and Informal Learning. The Internet and Higher Education, 15(1), 3-8.

Dalal, H. A. \& Lackie, R. J. (2014). What if you build it and they still won't come? Addressing Student Awareness of Resources and Services with Promotional Videos. Journal of Library \& Information Services in Distance Learning, 8(3-4), 225-241.

Daniel, D. (2015). Library Research Courses that Follow Universal Design Principles and Best Practices for Online Education of Special Needs Students Improve Student Learning Experiences. Evidence Based Library and Information Practice, 10(1), 69-71.

Davis, M. G. \& Smith, C. E. (2009). Virtually Embedded: Library Instruction within Second Life. Journal of Library \& Information Services in Distance Learning, 3(3-4), 120-137.

Day, S. (2015). Mobile Information Literacy Curriculum. Technology \& Social Change Group and the Henry M. Jackson School of International Studies. https://digital.lib.washington.edu/researchworks/handle/1773/34803 Accessed 16 October 2017.

Ebner, M., Schön, S., Taraghil, B., Drachsler, H., Tsang, P. (2011). First Steps towards an Integrated Personal Learning Environment at the University Level. In R. Kwan, C. McNaught, P. Tsang, F. L. Wang \& K. C. Li (Eds.), Enhancing Learning Through Technology: Education Unplugged: Mobile Technologies and Web 2.0 (pp. 22-36). Heidelberg: Springer.

Fong, W. W. (2013). The Trends in Mobile Learning. In: S. K. S. Cheun, J. Fong, W. Fong, F. L. Wang, L. F. Kwok (Eds.), Hybrid Learning and Continuing Education. ICHL 2013. Lecture Notes in Computer Science (pp. 301-312). Heidelberg: Springer.

Fundación Telefónica (2017). Sociedad digital en España 2017. Madrid/Barcelona: Fundación Telefónica. Editorial Ariel.

Gallego Lema, V., Cristóbal, M., Alberto, J., Arribas Cubero, H., \& Rubia Avi, B. (2016). Aprendizaje ubicuo: un proceso formativo en educación física en el medio natural. Revista Latinoamericana de Tecnología Educativa, 15(1), 59-73.

Gikas, J., \& Grant, M. M. (2013). Mobile Computing Devices in Higher Education: Student Perspectives on Learning with Cellphones, Smartphones \& Social Media. The Internet and Higher Education, 19, 18-26.

Glassman, J. A., \& Worsham, D. M. (2017). Digital Research Notebook: A Simple Tool for Reflective Learning. Reference Services Review, 45(2), 179-200.

Godwin, P. (2010). Information Literacy Gets Mobile. In G. Needham \& M. Ally (Eds.), M-libraries 2: A Virtual Library in Everyone's Pocket (pp. 206-213). London: Facet.

Greenlee, P. (2014). Tutorials: Resource Instruction for Distance Learners. The Christian Librarian, 57(2), 5.

Greer, K., Hess, A. N., \& Kraemer, E. W. (2016). The Librarian Leading the Machine: A Reassessment of Library Instruction Methods. College \& Research Libraries, 77(3), 286-301.

Gunn, M., \& Kraemer, E. W. (2011). The Agile Teaching Library: Models for Integrating Information. In Kelsey, S., \& Amant, K. (2011). Computer-Mediated Communication: Issues and Approaches in Education: Issues and Approaches in Education. Hershey, PA (USA): IGI Global. 
Gunn, M., \& Miree, C. E. (2012). Business Information Literacy Teaching at Different Academic Levels: An Exploration of Skills and Implications for Instructional Design. Journal of Information Literacy, 6(1), 18-34.

Hahn, J. (2008). Mobile Learning for the Twenty-First Century Librarian. Reference Services Review, 36(3), 272-288.

Havelka, S. (2013). Mobile Information Literacy: Supporting Students' Research and Information Needs in a Mobile World. Internet Reference Services Quarterly, 18(34), 189-209. http://dx.doi.org/10.1080/10875301.2013.856366 Accessed 16 October 2017.

Havelka, S., \& Verbovetskaya, A. (2012). Mobile Information Literacy. Let's Use an App for That! C\&RL News, January 2012. http://academicworks.cuny.edu/cgi/viewcontent.cgi? article $=1064 \&$ context=le_pubs Accessed 16 October 2017.

Hemmig, W., Johnstone, B. T., \& Montet, M. (2012). Create a Sense of Place for the Mobile Learner. Journal of Library \& Information Services in Distance Learning, 6(3-4), 312-322.

Hess, A. N. (2015). Motivational Design in Information Literacy Instruction. Communications in Information Literacy, 9(1), 44-59.

Hsieh, P. N., Chuang, T. M., \& Wang, M. L. (2013). A Bibliometric Analysis of the Theses and Dissertations on Information Literacy Published in the United States and Taiwan. Advances in Intelligent Systems and Applications, 1, 337-348.

Hsu, Y. C., \& Ching, Y. H. (2015). A Review of Models and Frameworks for Designing Mobile Learning Experiences and Environments. Canadian Journal of Learning and Technology, 41(3),1-22.

Hu, C. P., Hu, J. M., Deng, S. L., \& Liu, Y. (2013). A Co-Word Analysis of Library and Information Science in China. Scientometrics, 97(2), 369-382.

Humanante-Ramos, P., García-Peñalvo, F., \& Conde-González, M. (2017). Entornos personales de aprendizaje móvil: una revisión sistemática de la literatura. RIED. Revista Iberoamericana de Educación a Distancia, 20(2). http://revistas.uned.es/index.php/ried/article/view/17692 Accessed 30 October 2017.

Hung, J. L., \& Zhang, K. (2012). Examining Mobile Learning Trends 2003-2008: A Categorical Meta-Trend Analysis Using Text Mining Techniques. Journal of Computing in Higher Education, 24(1), 1-17.

Hwang, G. J., \& Chang, H. F. (2011). A Formative Assessment-based Mobile Learning Approach to Improving the Learning Attitudes and Achievements of Students. Computers \& Education, 56(4), 1023-1031.

Jacobs, W. N. (2017). Online Discussion in a Hybrid Information Literacy Credit Course. Education Libraries, 30(2), 18-26.

Johnson, M., Hollins, P., Wilson, S., \& Liber, O. (2006). Towards a Reference Model for the Personal Learning Environment. In L. Markauskaite, P. Goodyear \& P. Reimann (Eds.),23rd Annual Conference of the Australasian Society for Computers in Learning in Tertiary Education (pp. 385- 389). Sydney: Sydney University Press.

Kimberly, M. (2017). Research Plus ${ }^{\mathrm{TM}}$ Mobile App: Information Literacy "On the Go". Reference Services Review, 45(1), 38-53. https://doi.org/10.1108/RSR-03-20160020 Accessed 16 October 2017.

Kingsawat, K., Kwiecien, K., \& Tuamsuk, K. (2015). Components and Factors in Integrating Information Literacy Instruction in Elementary Education Using a Virtual Learning Environment. LIBRES: Library and Information Science Research Electronic Journal, 25(1), 50-77.

Kolle, S. R. (2017). Global Research on Information Literacy: A Bibliometric Analysis from 2005 to 2014. The Electronic Library, 35(2), 283-298.

Kong, L. X., Hunter, S. L., \& Lin, G. C. I. (2007). An Advanced Virtual Program in Engineering Education for Research and Teaching Excellence. International Journal of Mechanical Engineering Education, 35(2), 148-165. 
Kratochvil, J. (2014). Efficiency of e-Learning in an Information Literacy Course for Medical Students at the Masaryk University. The Electronic Library, 32(3), 322-340.

Kumar, R. (2016). Use of e-Resources by the Medical Students of MM University, Ambala: A Case Study. DESIDOC Journal of Library \& Information Technology, 36(1).10-16.

Kumar, S., Ochoa, M., \& Edwards, M. (2012). Considering Information Literacy Skills and Needs: Designing Library Instruction for the Online Learner. Communications in Information Literacy, 6(1), 91-116.

Ladell-Thomas, J. (2012). Do-it-yourself Information Literacy: Self-directed Learning at a Distance. Journal of Library \& Information Services in Distance Learning, 6(3-4), 376-386.

Majid, S., Chang, Y. K., Hnin, N. A., Ma, M. W. K., \& San, Y. W. (2015). Analyzing Publishing Trends in Information Literacy Literature: A Bibliometric Study. Malaysian Journal of Library \& Information Science, 20(2), 51-66.

Martin, F., \& Ertzberger, J. (2013). Here and Now Mobile Learning: An Experimental Study on the Use of Mobile Technology. Computers \& Education, 68, 7685.

Mateus, J. C., Aran-Ramspott, S., \& Masanet, M. J. (2017). Revisión de la literatura sobre dispositivos móviles en la universidad española. RIED. Revista $\begin{array}{llll}\text { Iberoamericana de Educación 20(2). } & \text { Distancia, }\end{array}$ http://revistas.uned.es/index.php/ried/article/view/17710 Accessed 30 October 2017.

Mery, Y., DeFrain, E., Kline, E., \& Sult, L. (2014). Evaluating the Effectiveness of Tools for Online Database Instruction. Communications in Information Literacy, 8(1), 70-81.

Mery, Y., Newby, J., \& Peng, K. (2012). Why One-Shot Information Literacy Sessions are not the Future of Instruction: A Case for Online Credit Courses. College \& Research Libraries, 73(4), 366-377.

Mestre, L. S., Baures, L., Niedbala, M., Bishop, C., Cantrell, S., Perez, A., \& Silfen, K. (2011). Learning Objects as Tools for Teaching Information Literacy Online: A Survey of Librarian Usage. College \& Research Libraries, 72(3), 236-252.

Moghaddam, H. S., \& Fard, E. M. (2013). Information Literacy in Distance Education Universities in Iran: A Case Study of Payame Noor University. International Journal of Information Science and Management (IJISM), 12(1), 65-76.

Mullins, K. (2017). Research Plus ${ }^{\mathrm{TM}}$ Mobile App: Information Literacy "On the Go". Reference Services Review, 45(1), 38-53.

Mune, C., Goldman, C., Higgins, S., Eby, L., Chan, E. K., \& Crotty, L. (2015). Developing Adaptable Online Information Literacy Modules for a Learning Management System. Journal of Library \& Information Services in Distance Learning, 9(1-2), 101118.

Nakayama, M., Mutsuura, K., \& Yamamoto, H. (2014). Impact of Learner's Characteristics and Learning Behaviour on Learning Performance during a Fully Online Course. Electronic Journal of e-Learning, 12(4), 394-408.

Panda, I., Maharana, B., \& Chhatar, D.C. (2013). The Journal of Information Literacy: a Bibliometric Study. International Journal of Scientific and Research Publications, 3(3), 1-5.

Park, M. K., \& Kim, H. J. (2011). A Bibliometric Analysis of the Literature on Information Literacy. Journal of the Korean Society for Information Management, 28(2), 53-63.

Peter, J., Leichner, N., Mayer, A. K., \& Krampen, G. (2017). Making Information Literacy Instruction more Efficient by Providing Individual Feedback. Studies in Higher Education, 42(6), 1110-1125.

Pinto, M. (2015). Viewing and Exploring the Subject Area of Information Literacy Assessment in Higher Education (2000-2011). Scientometrics, 102, 227-245. 
Pinto, M., Escalona, M. I., \& Pulgarín, A. (2013). Information Literacy in Social Sciences and Health Sciences: A Bibliometric Study (1974-2011). Scientometrics, 95(3), 1071-1094.

Rau, P. L. P., Gao, Q., \& Wu, L. M. (2008). Using Mobile Communication Technology in High School Education: Motivation, Pressure, and Learning Performance. Computers \& Education, 50(1), 1-22.

Russell, P., Ryder, G., Kerins, G., \& Phelan, M. (2013). Creating, Sharing and Reusing Learning Objects to Enhance Information Literacy. Journal of Information Literacy, 7(2), 60-79.

Schmidt Hanbidge, A., Sanderson, N., \& Tin, T. (2016). Information Literacy on the Go! Adding Mobile to an Age Old Challenge. International Association for Development of the Information Society, Portugal. http://files.eric.ed.gov/fulltext/ED571443.pdf Accessed 16 October 2017.

Serin, O. (2012). Mobile Learning Perceptions of the Prospective Teachers (Turkish Republic of Northern Cyprus Sampling). TOJET: The Turkish Online Journal of Educational Technology, 11(3), 222-233.

Špiranec, S., \& Banek Zorica, M. (2010). Information Literacy 2.0: Hype or Discourse Refinement? Journal of Documentation, 66(1), 140-153.

Sproles, C., Detmering, R., \& Johnson, A. M. (2013). Trends in the Literature on Library Instruction and Information Literacy, 2001-2010. Reference Services Review, 41(3), 395-412.

Su, C. H., \& Cheng, C. H. (2015). A Mobile Gamification Learning System for Improving the Learning Motivation and Achievements. Journal of Computer Assisted Learning, 31(3), 268-286.

Tallolli, S. B., \& Mulla, K. R. (2016). A Bibliometric Analysis of Journal of Information Literacy (2011 to 2015). ISST Journal of Advances In Librarianship, 7 (2), 44-51.

Tang, C. M., \& Chaw, L. Y. (2016). Digital Literacy: A Prerequisite for Effective Learning in a Blended Learning Environment? Electronic Journal of e-Learning, 14(1), 54-65.

Taşkın Z., Doğan G., Şencan İ. (2013) Analyzing the Intellectual Structure of World Information Literacy Literature through Citations and Co-citations. In: Kurbanoğlu S., Grassian E., Mizrachi D., Catts R., Špiranec S. (Eds.), Worldwide Commonalities and Challenges in Information Literacy Research and Practice. ECIL 2013. Communications in Computer and Information Science (pp. 54-60). Cham: Springer.

Thornes, S. L. (2012). Creating an Online Tutorial to Support Information Literacy and Academic Skills Development. Journal of Information Literacy, 6(1), 81-95.

Tomberg, V., Laanpere, M., Ley, T., and Normak, P. (2013). Sustaining Teacher Control in a Blog-Based Personal Learning Environment. International Review of Research in Open and Distance Learning, 14(3), 109-133.

Traxler, J. M. (2008). Use of Mobile Technology for Mobile Learning and Mobile Libraries in a Mobile Society. In: G. Needham \& M. Ally (Eds.), M-libraries: Libraries on the Move to Provide Virtual Access (pp. 47-55). London: Facet.

Türker, M. A., \& Zingel, S. (2008). Formative Interfaces for Scaffolding SelfRegulated Learning in PLEs. eLearning Papers, 9, 1-15. http://goo.gl/vWyJ5k Accessed 20 May 2018.

Ukwoma, S. C., Iwundu, N. E., \& Iwundu, I. E. (2016). Digital Literacy Skills Possessed by Students of UNN, implications for Effective Learning and Performance: A Study of the MTN Universities Connect Library. New Library World, 117(11/12), 702720 .

Uribe-Tirado, A., \& Alhuay-Quispe, J. (2017). Estudio métrico de ALFIN en Iberoamérica: de la bibliometría a las altmetrics. Revista Española de Documentación Científica, 40(3). http://redc.revistas.csic.es/index.php/redc/article/view/984/1518 Accessed 20 May 2018. 
Urs, S., Raghavan, K. S., Anuradha, K. T., \& Harinarayana, N. S. (2013). A Bibliometric Study of World Research Output on Information Literacy in the Field of Library and Information Science during 1999-2013. In H. P. Shekar, H. Rajendra Babu, V. Sunitha \& T. A. Mohan (Eds.), National Conference on Inspiring Library Services (NCILS-2013) (Vol. 1, pp.1-5). Tumkur, Karnataka: Sree Siddharta Education Society.

Van Eck, N.J., \& Waltman, L. (2010). Software Survey: VOSviewer, a Computer Program for Bibliometric Mapping. Scientometrics, 84(2), 523-538.

Van Harmelen, M. (2006). Personal Learning Environments. Proceedings of the Sixth International Conference on Advanced Learning Technologies (ICALT'06). https://goo.gl/eD4voC Accessed 21 May 2018.

Vassilakaki, E. (2014). Mobile Information Services in Libraries: A Review of Current Trends in Delivering Information. Interlending \& Document Supply, 42(4), 176186.

Virkus, S. (2006). Development of Information-Related Competencies in European ODL Institutions: Senior Managers' View. New Library World, 107(11/12), 467-480.

Virkus, S. (2012). Information Literacy from the Policy and Strategy Perspective. Nordic Journal of Information Literacy in Higher Education, 4(1), 16-37.

Wales, T., \& Robertson, P. (2008). Captivating Open University Students with Online Literature Search Tutorials Created Using Screen Capture Software. Program, 42(4), 365-381.

Walsh, A. (2012a). Using Mobile Technology to Deliver Library Services: A Handbook. London: Facet - CILIP.

Walsh, A. (2012b). Mobile Information Literacy: A Preliminary Outline of Information Behaviour in a Mobile Environment. Journal of Information Literacy, 6(2), 56-69.

Walters, K., Bolich, C., Duffy, D., Quinn, C., Walsh, K., \& Connolly, S. (2015). Developing Online Tutorials to Improve Information Literacy Skills for Second-Year Nursing Students of University College Dublin. New Review of Academic Librarianship, 21(1), 7-29.

Washburn, A. (2009). Screencasting Library Tutorials for Distance Learners: A User Evaluation. Indiana Libraries, 28(3), 49-57.

Wilson, S., Liber, O., Johnson, M., Beauvoir, P., Sharples, P., Milligan, C. (2006). Personal Learning Environments: Challenging the Dominant Design of Educational Systems. Journal of e-Learning and Knowledge Society, 3(2), 27-38.

Woodward, K. M. (2015). Students at the Center in Emerging Academic Models: Embedded Information Literacy and Distance Services in the University of Wisconsin System Flex Degree. Library Hi Tech News, 32(7), 12-15.

Zipf, G. K. (1940). The Generalized Harmonic Series as a Fundamental Principle of Social Organization. The Psychological Record, 4, 41-43. 